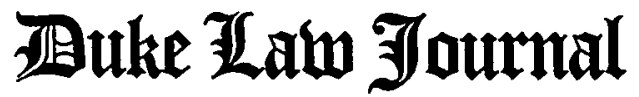

NUMBER 6

\section{ANTITRUST \\ PROSCRIPTION AND THE MASS MEDIA}

\begin{abstract}
Arthur D. Austin*
The shift in the business world's primary concern from one of greater industrial expansion to the present race in consumer motivation and concomitant marketing processes has elevated mass media to new importance in antitrust analytics. The author contends that the Supreme Court is moving far too slowly in accomodating the mass-media phenomenon to conventional antitrust wisdom. After examining the impact of nlass media in the economic setting, and the Court's halting response, the author urges that only a radical change in antitrust perspective can hope to account for this institutional force in future decisions.
\end{abstract}

\section{INTRODUCTION}

$\mathrm{T}$ HE SUBTLETIES and complexities of the contemporary mass media culture are just now being given serious recognition as a meaningful and decisive force in trade regulation analysis.' The courts, however, have not distilled conclusions and judgments from this recognition of sufficient consistency and depth necessary to support durable predictions as to future policy trends. Yet ragged and hesitant judicial analysis is hardly unanticipated. The difficulties involved in measuring the consequences that various promotional

\footnotetext{
* B.S. 1958, University of Virginia; LL.B. 1963, Tulane University. Assistant Professor of Law, Case IVestern Reserve University.

'The focus of this recognition has been on the Supreme Court level: U.S. v. Arnold, Schwinn \& Co., 388 U.S. 365 (1967); FTC v. Procter \& Gamble Co., 386 U.S. 568 (1967); FTC v. Borden Co., 383 U.S. 637 (1966); FTC v. Colgate-Palmolive Co., 380 U.S. 374 (1965); U.S. v. Continental Can Co., 378 U.S. 441 (1964). Accordingly, when concerned with judicial inquiry, this study will be, for the most part, restricted to the expressions of the Supreme Court.
} 
techniques have on the marketplace justify caution. Perhaps the most imposing obstacle to lucid and descriptive analysis is a deeply rooted conditional reflex action to the traditions of antitrust dogma that is strikingly manifested in endeavors to weave the decisional thread of new problem solving into the comfort and ease of the familiar fabric of established perspective.

Mass media, as used in this article, draws its definitive boundaries from two sources-methodology and technology.2 Sophisticated advertising techniques, the employment of psychological theory, and the use of in-depth surveys are but some of the contemporary methodologies utilized to influence and, assertedly, to mold the decision making patterns of the public. Modern technology is used as a conduit through which expressions of the method can be conveyed to the public and also as a means of expanding and reinforcing the message. The technology of mass media is not restricted to print, radio, and television. The automobile, for example, communicates style and fashion-its very existence serves as a conditioning force on society. Whatever the results of inclusion and exclusion in defining the instrumentalities of technology and methodology, one thing is clear-the purpose of mass media is to influence people. It is this dominating purpose that has, with the aid of some substantial alterations in the economy (that are either resultant, causative, or both), culminated in the creation of a new economic and social institution-the mass media culture.

Furnishing additional emphasis to the importance of ascertaining the consequences of the mass media culture on antitrust interpretation is the presence of evidence indicating that the same force is becoming a dominant source of tension in economic analysis. Perhaps the best method of approaching the problem in its broadest scope is to examine the texture and quality of the relationship between historical

\footnotetext{
: To commentators within the marketing field, mass media has a rather narrow meaning. They restrict the term to the forms and types of instruments that can be used to convey and expose the message to the group objective. E. BRINK \& WV. KELLLLIY. TIII: MANAGINULNT OF Pronorion 253-54 (1963); A. FriY. Advertising 234-309 (3d ed. 1961). By integrating methodology and technology as I have done in this study, the definitive scope of mass media has been significantly expanded. Basic to this expanded vicw is the assumption that message content and mode of conveyance merge-resulting in a different effect. An example of the consequences of this merger is reflected in the package. The message, printed on the wrapping, combined with the vehicle, i.e.. the package, creates an effect that defies fragmatized analysis. For an example of the trade regulation problems posed by packaging see Gerber Prods. Co. v. Beech-Nut Life Savers, Inc., 160 F. Supp. 916 (S.D.N.Y. 1958).
} 
and traditional antitrust norms and the actual and assumed market consequences of mass-media pressures. In order to establish a frame of reference, it is necessary briefly to trace the development of those concepts that have relevance to mass-media analysis. This inquiry, in conjunction with related excursions, hopefully will provide foundational perspectives on methods by which mass media can be meaningfully recognized in antitrust decision making.

\section{The Traditions of Trade Regulation}

\section{A. The Early Thrust Towards Conduct}

The original core of the antitrust repertory, sections 1 and 2 of the Sherman Act, ${ }^{3}$ section $3^{4}$ and section 7 of the Clayton Act, ${ }^{5}$ and the Federal Trade Commission Act, ${ }^{6}$ represents a reaction to the marketplace violence moulded by an emerging nation in the throes of industrialization. It was a period characterized by tenacious and unyielding conduct, typically manifested in cut-throat competition and the aggrandizing pressures of trusts and holding companies. ${ }^{7}$ The tactics were rough, but to the late 19th century capitalist this type of conduct was merely a justifiable expression of the rugged individualism of Social Darwinism. ${ }^{8}$ Thus, it is hardly surprising that the original trade regulation statutes were conduct oriented." Contracts in restraint of trade, monopolization, unfair methods of competition, and mergers, all embraced under the various statutes, represented types of conduct thought to be harmful and hence worthy of proscription.

Equally relevant to the early antitrust zeitgeist was a complete reliance on the ideal of the "perfect" competition model. It was assumed that if predatory forms of conduct could be erased, the abstract model of perfect competition would immediately descend upon the marketplace, creating a utopia of numerous buyers and sellers, all informed as to their respective activities, with full

'26 Stat. 209 (1890) (codified at 15 U.S.C. $\$ \$ 1,2$ (1964)).

+38 Stat. 731 (1914) (codified at 15 U.S.C. $\$ 14$ (1964)).

:64 Stat. 1125 (1950) (codified at 15 U.S.C. $\$ 18(1964))$.

- 38 Stat. 719 (1914) (codilied at 15 U.S.C. $\$ 45$ (1964)).

'See H. Thorlilli. Thil Filderal ANTITRust Policy 67-68 (1955).

* This perspective was apparently shared by the bench and bar. S. FINE, LAISSEZ FaIRE AND TH: Gent:Ral-Wlilfarl: State 138-39 (1956).

'Defining conduct in terms of force, Kaysen and Turner conclude that "there are three possible kinds of force which a firm can resort to: violence (or the threat of it), deception, or market power." C. KAySEN \& D. TURNer. ANTITRUST POLICY 17 (1965). 
knowledge of product substitutes, etc. This, of course, reinforced the focus on behavior and simultaneously obscured inquiry into structural causes and effects.

\section{B. The Depression: Confusion, Reappraisal, and New Ideas}

The thread of trade regulation development, along with the movement of economic thought, received a severe jolt from the 1929 Wall Street debacle and the subsequent depression. From that moment on, the economy was never to be taken for granted. The response to the depression clearly delineated two clashing lines of thought--economic planners and antitrusters. After an unsuccessful shot-gun marriage under the umbrella of the abortive National Industrial Recovery Act of 1933, each side went its separate and polemical path. ${ }^{10}$

The courts and antitrusters did not abandon conduct orientation. On the other hand, a subtle shift in perspective did occur. Conduct became a component, a dominant component, of a broader analysis. The texture of marketplace activity was examined on an industry by industry basis, and where competition was absent Government prosecution zeroed in on that conduct thought to be the causative force." For example, the basing-point system fel[ ${ }^{12}$ and the use of concerted buying power in the movie industry was eliminated. ${ }^{13}$ The intra-industry relationship of the competing (or non-competing) firms took on new significance. The final result was that structural examination, albeit tentative, became a by-product of the Government's prosecution methodology.

Not only did the ferment of the depression usher in structural awarcness, however tentative, but it also witnessed the end of an economy constructed around the routine of heavy industrial expansion. Techniques designed to oust competitors in distribution and marketing became the vogue in the struggle to dominate. An economic order predicated on the tenets of mass production was absorbed into a society geared to mass consumption. From a concern with the manufacturer's role in amassing and exploiting productive resources, the emphasis shifted to the intermediary distributor's use of

\footnotetext{
"See generally E. Hawley, The New Deal and the Problen of Monopoly (1966); A. SCHLesinger, THE COMING OF THE NEW DEAL (1959).

"E. HAWLEY, supra note 10, at 428.

"Corn Prods. Ref. Co. v. FTC, 324 U.S. 726 (1945).

"U.S. v. Crescent Amusement Co., 323 U.S. 173 (1944).
} 
massive and concentrated purchasing power..$^{14}$

The Robinson-Patman Act ${ }^{15}$ was the statutory solvent to this change in emphasis. Although still directed towards conduct (price discrimination), the Act represented a departure from the alignment of its legislative predecessors. Heretofore, conduct prohibition had been used to restore and maintain a competitive equilibrium that was constructed upon certain theoretical assumptions concomitant to "perfect" condition. Under the Robinson-Patman Act, however, behavior by some members of an industry was to be proscribed so as to build a protective shield around a competing group of smaller and independent purchasers.

It has not been easy to relate the Robinson-Patman Act to the commercial scene. Turner noted that "protection of a certain class of competitors may yield different results from protection of the competitive process generally, particularly where the protected class is threatened by more efficient techniques."16 Whatever the true nature of its relationship with the antitrust corpus, ${ }^{17}$ the Act did have two effects that are relevant to this article. First, it introduced to the judicary and trade-regulation critics a new and rapidly emerging phase of the economy-the promotion and marketing of products. ${ }^{18}$ Secondly, the marketplace, viewed in terms of consumption, became the point of departure for inquiry. Thus the courts were but a step away from tangling with the nuances of massmedia-inspired consumer behavior.

In the final analysis the most oustanding characteristic of the New Deal era was the sweeping reappraisal of the economy. Congressional hearings, Government-sponsored reports, and private inquiry, plus the appearance of studies like Edward Chamberlin's The Theory of Monopolistic Competition, cast doubt on the relevance of the a priori

it The most significant method of distribution was, of course, the chain store. For two cxcellent studies of this phenomenon see H. Barger, Distributions' Place in the AMerican Économy SinCE 1869 (Nat'l Bureau of Economic Research, Gen. Series No. 58, 1955), and J. Palamountain, The Politics of Distribution (1958).

is 49 Stat. 1526 (1936) (codified at 15 U.S.C. $\$ 13$ (1964)).

${ }^{16}$ Turner, The American Antitrust Laws, 18 Modern L. Rev. 244, 249 (1955).

17 It has been argued that the Robinson-Patman Act is, in terms of policy, at cross-purposes with the Clayton and Sherman Acts. See Adelman, Effective Competition and the Antitrust Laws, 61 HaRv. L. Rev. 1289, 1327-50 (1948); Burns, The Antitrust Laws and the Regulation of Price Competition, 4 Law \& Contemp. Prob. 301 (1937).

18 An investigation by the FTC resulted in a specific finding that one significant chain store advantage was "the ability . . . to realize the benefits of large-scale advertising . ..." C. Edwards, The Price Discrimination law 10 (1959). 
models of "perfect" competition and "pure" monopoly. The conduct approach to antitrust slowly began to lose favor. Many economists adopted the view that tight conduct control was ineffectual when the market structure that generated the harmful practices remained intact. If oligopolists could make seemingly independent decisions but nevertheless arrive at similar conclusions, and if the competition's every move could be anticipated, any effort effectively to proscribe conduct under traditional interpretations would probably be futile. Nevertheless, conduct scrutiny did not disappear. What did occur was a shift in perspective that was guided by the appearance of structural analytics.

\section{Contemporary Views on Trade Regulation}

\section{A. The Concentration Mystique}

Structural analytics now provides the most vigorous sense of direction for the implementation of trade-regulation laws. ${ }^{19}$ Structural analytics stands for the proposition that the basic elements of market architecture-factors such as conditions of entry, product characteristics, the number of firms, and the degree of concentration-have a strong, if not conclusive, bearing on the ultimate disposition of antitrust violation charges. ${ }^{20}$ Of these factors, what has been characterized as "the rising tide of economic concentration" has generated the greatest interest."

The post World War II merger binge, documented in Federal Trade Commission reports and exposed in Congressional hearings, ${ }^{22}$ precipitated the injection of strong proscriptive powers into what had been an anemic antimerger act. The focus shifted from the full-blown behavior of Sherman Act proportions to the anticipatory authority to stop mergers at that point "when the trend to a. lessening of competition in a line of commerce is still in its incipiency." ${ }^{23}$ The scope and the boundaries of analysis open to the judiciary was

14 "Only by focusing on market structure can we begin to formulate standards which will allow the responsible agencies to give proper consideration to such mergers and allow businessmen to plan their actions with a fair degree of certainty." FTC v. Procter \& Gamble Co., 386 U.S. 568, 592 (1967) (concurring opinion).

30 G. Hale \& R. Hale, Market Power: Size and Shape Under the Sherman Act 89.169 (1958); G. Stocking, Workable Competition and ANTitrust Policy 122 (1961).

"Brown Shoe Co.v. United States, 370 U.S. 294, 315 (1962).

Id. at 315 n.27.

Id. at 317 . 
therefore considerably expanded, thus making possible a more searching and incisive awareness of conduct. Seemingly innocuous behavior is now suspect if it adversely alters the structural framework of a market. For example, reciprocal trading, a practice that long existed with impunity in day-to-day commercial transactions, ${ }^{24}$ was recently struck down by the Supreme Court. ${ }^{25}$

\section{B. "Lessening of Competition" and Conduct}

Not only are what might be called dormant types of conduct becoming relevant, but the patterns of interpretation given recognized practices are being reshaped to fit the demands of the structural ethic. Practices that at one time were prohibited only if part of a grand scheme of monopolistic coercion are today condemned if they interfere with structural symmetry. A profile of the tying arrangement chronicles this shift in emphasis. Proscription originally depended upon whether the defendant occupied "a dominating position" 26 in the market for the tying product. Now all that is necessary for successful prosecution is "sufficient economic power to impose an appreciable restraint on free competition in the tied product. . . ."27

In other words, the significant factor is foreclosure in the market for the tied item. This is because foreclosure has an effect not only on existing competitors, but also on potential competitors standing at the edge of the market. The structural significance of any endeavor by established firms to insulate themselves from new competition is obvious. Such behavior would have the effect of assuring the emergence of an oligopolistic setting. Or, if the industry was already an oligopoly, the barriers to entry erected by foreclosure would greatly magnify the existing and already formidable power of the dominant firms. The result might be the creation of collective barriers. ${ }^{28}$ Hence the higher the foreclosure quantum of the behavior under scrutiny, the greater the likelihood of it receiving per se treatment. Conversely, as the foreclosure nexus between conduct and structural analytics lengthens, the greater is the plaintiff's burden of proof.

:s Lewis, The Present Status of Reciprocity as a Sales Policy. 16 HARv. Bus. Rev. 299 (1938). A 1961 study confirmed these findings. Sloan, Reciprocity: Where Does the P.A. Stand? Purchasing, Nov. 20, 1961, at 70, 71 .

" FTC y. Consolidated Foods Corp., 380 U.S. 592 (1965).

: United Shoe Mach. Corp. v. United States, 258 U.S. 451, 458 (1922).

"Northern Pac. Ry. v. United States, 356 U.S. I, 11 (1958).

${ }^{28}$ Standard Oil Co. v. United States, 337 U.S. 293, 309 (1949). 
It is very patent that in post World War 11 decisions courts have imputed a varying standard, almost always manifested in terms of a structural frame of reference, into the qualifying clause "may be to substantially lessen competition ....."29 "Competition" in a very real sense is closely identified with an accessible market structure. Conduct that impedes market accessibility carries with it what is becoming an increasingly harsh burden of justifying its existence. Activities no longer escape condemnatory analysis because they are not predatory within traditional interpretations. The relevance of this shift in perspective to mass-media activity is, of course, manifest.

\section{Treatise Influence on Judicial Decision Making}

There is perhaps no other area of law that has been so heavily influenced by non-judicial commentary as antitrust. ${ }^{30} \mathrm{~A}$ direct consequence of this influence has been the emergence of two closely related bench marks that seem to play a significant role in shaping the court's final conclusion.

Any activity that contributes to the erection of barriers to market entry is suspect. "Without this condition [freedom of entry], it is idle to expect effective competition." 31 More specifically, it is thought that the economies of large-scale advertising and sales promotion can make it impossible for new entrants to compete on favorable terms. ${ }^{32}$ Not only do commentators dwell at some length on the role that the advertising budget plays when there is an actual attempt to break into a market but, in addition, there is a mounting preoccupation with the effect that mass media has on firms standing at the edge-merely

\footnotetext{
₹9 This terminology is contained in $\$ \S 3$ and 7 of the Clayton Act, 15 U.S.C. $\$ \$ 13,18$ (1964), and in $\$ 2$ (a) of the Robinson-Patman Act, 15 U.S.C. $\$ 13$ (1964).

${ }^{30}$ In addition to Chamberlin's treatise, the following works have been influential: J. BaIN, Barriers to New Competition (1965); J. Gallbraith, American Capitalism (1952); C. Kaysen \& D. TUrner, Antitrust Policy: An Economic and Legal analysis (1959); J. Schumpeter, CaptTalisi, Socialisi, And Democracy (1942); Clark, Toward a Concept of Workable Competition, 30 AN. ECon. Rev. 24 I (1940).

"Report of the Attorney General's National Committee to Study the Antitrust LAwS 326 (1955).

32 The emphasis on a relationship between barriers to entry and advertising resulted mainly from the influence of economists, particularly Chamberlin and Robinson, who cmancipated "the analysis of markets from the inadequate categories of competition and single firm monopoly. Their views rapidly achieved widespread acceptance, and almost at once the concepts of duopoly, oligopoly and the purposeful differentiation of products became accredited categories in market analysis. The theory brought the vast phenomenon of merchandising and advertising within the scope of theoretical discussion." G. HALE \& R. HALE, supra note 20, at 90.
} 
contemplating entry. ${ }^{33}$ The second bench mark through which massmedia analysis becomes crucial is product differentiation. ${ }^{34}$ lts relationship to the entry condition is obviously very close: "Logically, this might be seen as another element in the conditions of entry, but it is important enough to warrant distinction." 35 Advertising and sales promotion are utilized so as to develop a strong product image in the consumer's mind, thus constructing a near-impregnable wall of preference and good will that can be pierced by actual or would-be competitors only at a considerable investment of both time and money. ${ }^{36}$

\section{V. A "People of Plenty"lnundated by the Mass-Media T.ECHNIQUE}

The syntexical economy of the judicial opinion transports at best a much distilled version of the acutal scope and command of mass media. Omitted is the fact that the "anonymous voices of the mass media"37 have pervaded the climate of our society to the extent that its status as a (or, arguably, as "the") dominant influence in contouring cultural patterns can no longer be seriously questioned. There are two factors of a technical nature that help to explain its vigor and authority: One is the startling advances that have been made in communication projection, while the second is the use of sophisticated methods both to ascertain and to utilize consumer urges. Both of these forces are pertinent to emerging trends in antitrust thinking. To complete the perspective it is necessary that these forces be examined as they relate to the character of the nation's social and economic milieu.

\footnotetext{
${ }^{3}$ See J. Bain, supra note 30, at I1-19.

" Product differentiation "refers in essence to buyers' preferences for one or some of a variety of very similar substitute products, such as several brands of cigarettes or several makes of automobiles, and also to the fact that different buyers have different product allegancies or preference patterns, so that the preferences in question do not result in some universally agreedupon system of grading or rating for the competing products." J. BAIN, supra note 30, at 115.

"C. KAYSEN \& D. TURNER, supra note 30 , at 74.

${ }^{36}$ Bain concludes that as a result of product differentiation "the established firms should . . . be able to elevate their long-run price above minimal costs by some corresponding amount without attracting entry. The gap between price and minimal costs (included selling costs) which they can establish while forestalling entry will be a measure of the barrier to entry attributable to their product differentiation advantages." J. BaIN, supra note 30, at 116.

"D. Riesman, The Lonely Crowd 22 (Yale paperbound 1963).
} 


\section{A. Consumer Impulses and the National Character}

The needs and the debilitating tensions of an economy endeavoring to fulfill its industrial potential are no longer the modifying forces in the United States. Adam Smith's directive that "consumption is the sole end and purpose of all production" ${ }^{38}$ is now reality. The complete maturation of the productive process has resulted in the capitalist transferring the focus of his interest to the distributive and marketing processes. Today the strategy and policy of the nation's business establishment is heavily committed to developing methods of expanding favorable consumer responses.

The energy of these externals, combined with other more subtle forces, literally created a new form of culture ${ }^{39}$-and a new type of consumer. Whether he is characterized as a member of "the Affluent Society," one of "The People of Plenty" or whether he is called an "Organization Man" or a "Status Seeker," he is possessed of an insatiable urge to consume. David Riesman contends that guidance in consumer taste has, in effect, replaced training in etiquette. He concludes that in modern society the individual's "tremendous outpouring of energy is channelled into the ever expanded frontiers of consumption . . . ." Directing the flow of the consumer's energy is mass media.

\section{B. The Technology and Techniques of Mass Media}

An accurate measurement of the extent to which communication technology has contributed to the development of the massconsumption society is impossible. External description and general definition of the mechanics of the various devices pose no serious problems. The print on newspapers, the electrical impulses of television and radio are, in terms of mechanical performance, generally familiar to all. However, it is becoming increasingly evident that each mechanism creates different and perhaps unmeasurable stresses and tensions in the receiver. Whether or not there exists so

\footnotetext{
${ }^{38}$ A. Suith, The Wealth of Nations 625 (Modern Library ed. 1937).

${ }^{39}$ Cultural changes are, according to Professor Duesenberry, primarily responsible for consumption drives. J. Duesenberky, InCome, Savings, and the Theory of Consumer Behavior 26 (1967). See also W. Rostow, The Stages of Econonic Growth: A NonCOMMUNIST MANIFESTO 10 (1960).

${ }^{ \pm 0}$ Each of these titles represents a well known book dealing in part with the problems of consumption. The authors are respectively: J. Galbraith; D. Potter; W. Whyte, Jr.; V. Packard.

${ }^{+1}$ D. RIESMAN, supra note 37 , at 78.
} 
sharp a distinction, as Dr. McLuhan insists, between "hot" and "cool" media, the fact remains that to a great but unfathomable extent "the medium is the message." ${ }^{.2}$ Certainly the overall effects of the myriad of communication systems now part of everyday life has become so cumulative as to blend into the mores of the consumer's buying syndrome.

It is interesting to note that simultaneous with the emergence of a consumption-directed society, the advertising industry was in the process of developing and adopting revolutionary methods of reaching and influencing the consumer. By drawing from sociological and psychological testing techniques, advertisers are now able to obtain a three-dimensional view of the consumer. Depth interviews provide an insight into the potential purchaser's mind, thus allowing merchandisers to discern and exploit urges which might otherwise remain latent. Psychology and the social science disciplines have been invoked so extensively and frequently that they now form the essence of the contemporary advertising style. Progenies of these disciplines, such as determining and capitalizing on reference-group aspirations, gearing sales programs to class and ethnic variation, developing brand associations, along with other equally successful methods, have all been used at one time in the continuous endeavor effectively to exert influence on consumer purchasing habits. ${ }^{43}$

\section{Measures of Mass Media Success}

Generally speaking, the ultimate objective of mass-media sales promotion is the creation of a wall of impregnable brand loyalty-or what has also become known as product differentiation. ${ }^{44}$ How successful have merchandisers been in attaining the objective? Any precise measurement of advertising and promotion efficacy is extremely difficult. As John Wanamaker reputedly said: "I know half

42 McLuhan's thesis is that media shapes and modifies mankind. A shift in medium emphasis causes a corresponding alteration in the balance among the five senses, utlimately creating a new environment. Or, in McLuhan's words: "This is merely to say that the personal and social consequences of any medium-that is, of any extension of ourselves-result from the new scale that is introduced into our affairs by each extension of ourselves, or by any new technology." $M$. Mcluhan, Understanding Media: The Extensions of MAN 23 (Signet ed. 1964).

"See generally N. Borden, Advertising in Our Economy (1945); E. Brink \& W. Kelley, supra note 2; E. Cundiff \& R. Still, Basic Marketing (1964); A. Frey, AdVertising (3d ed. 1961); S. Otteson, W. Panschar \& J. Patterson, Marketing (1964).

s One important exception is the effort to convince the public that chemically and physically dissimilar products are interchangeable as to end use. See notes 134-41 infra and accompanying text. 
the money I spend on advertising is wasted, but I can never find out which half." 45 There are substantial problems in composing a qualitative test that will successfully provide answers to such questions as-what effect, if any, do certain types of copy have on consumer buying habits, or, how much does the form of media (and remember that there is obvious media differentiation existing in the communications industry) contribute to success? $?^{46}$

Quantitative forms of measurement have likewise proven inadequate. Statistical readings on the number of people who expose themselves at a given instant to promotional impulses does not accurately reflect how they will respond in terms of purchases. ${ }^{47}$ Translating the ups and downs of sales volume into a quantum of promotional effectiveness is also open to question. Increases in sales can be attributed to the consistent upswing in the economy and are therefore an inexorable feature of the consumption ethic. ${ }^{48}$

Increasing the difficulties of accurate measurement is the fact that mass media cannot automatically convert a product with declining sales into a market winner. Moreover, some products are seemingly oblivious to the suasions of the ad campaign. ${ }^{49}$ Finally, there are instances where well-planned and concentrated promotion has failed in striking fashion. ${ }^{50}$

Most of these criticisms are directed toward the accuracy of measurement-they do not dispute the fact or the success of the penetrating capacity of mass media to initiate and sustain predesigned purchasing patterns among the consuming public. This mastery is best reflected by the existence of what is commonly known as the "premium" or "prestigious" brand. A heavily-promoted

\footnotetext{
"s Quoted in M. Mayer, Madison Avenue, U.S.A. 259 (Cardinal ed. 1959).

${ }^{36}$ See generally Weilbacker, The Qualitative Values of Advertising Media, in J. WRIGHT \& D. WARNER, SPEAKING OF ADVERTISING 265-73 (1963).

"See G. Seehafter \& J. Laemmar, Successful Television and Radio Advertising 267. 94 (1959).

\& Professor Backman says: "Although cause-and-effect relationships are difficult to disentangle, it seems far more probable that the rise in economic activity has caused the rise in advertising rather than the reverse. But advertising was also causative of economic growth as well as its beneficiary. The postwar period has seen a flood of new products moving into mass consumption. To the extent that advertising has facilitated the development and acceptance of these products, it has contributed most constructively to economic growth." J. BACKMAN, ADVERTISING AND COMPETITION 8 (1967).

*9 See D. Ogilvy, Confessions of an Advertising Man 60 (1964).

${ }^{30}$ For a description of such an instance see General Foods is Five Billion Particulars, FORTUNE, March, 1964, at 163.
} 
premium brand, although containing the same chemical properties as the "private" branded item, commands a higher retail price.s1

Mass-media success is also reflected in the statutory and judicial protection of trade symbols. A trademark or name can, without extensive reinforcement, serve as a persuasive sales force. "With the expansion of markets ... and the development of large scale advertising, trademarks began to perform the additional function of an advertising and selling device. In the market, the chief value of a trademark may be its power to stimulate sales." 52 Hence, to throw a protective shield, via legislation, around trade symbols is to recognize that promotion is commercially efficacious and can have important economic value to the merchandiser..$^{53}$

\section{The Public View and Classification}

With some notable exceptions, ${ }^{54}$ social commentators have been extremely condemnatory in their treatment of mass media, with the nucleus of their censure directed toward advertising. ${ }^{55}$ After postulating that advertising goals can be neatly isolated and then boxed into two separate functions-informing and persuading-condemnation is without exception directed at the persuasive function. Promotional tactics seem to violate an ingrained Puritan ethic of rectitude and honesty by, in language attributed to Arnold Toynbee, "inducing us to do hard labor in order to find the money for buying material goods that we should never have dreamed of wanting if we had been left to ourselves ...."s6 Popular journalism, such as Vance Packard's The Hidden Persuaders and Frederic Wakeman's The Hucksters, has mordantly reinforced this view, resulting in a comprehensive and unshakeable suspicion of anything coming from Madison Avenue.

"1 For an analysis of branding policy see M. BORDEN, ADVERTISING IN OUR ECONOMY (1945).

32 Restatement of TORTS $\$ 715$, comment b (1938). The Supreme Court agrees: Mishawaka Rubber \& Wollen Mfg. Co.v.S.S. Kresge Co., 316 U.S. 203, 205 (1942).

${ }^{33}$ See C. Wilcox, Public Pōlicies Towànd Business 189 (3d ed. 1966).

st Perhaps the most outstanding exception is David Potter who, while recognizing the usual criticisms, nevertheless concludes that "the only institution which we have for instilling new needs, for training people to act as consumers, for altering men's values, and thus for hastening their adjustment to potential abundance is advertising." D. PotTer, People of Plenty 175 (Phoenix ed. 1954).

ss Suspicion and hostility toward advertising is by no means of recent origin. II Plato, Dialogues, Law'X 657 (B. Jowett, Oxford Univ., transl. 1937).

${ }^{36}$ Quoted in Larsen, Advertising: The Multiplier of Our Economy, J. WRiGHT \& D. WARNER, supra note 46 , at 445 . 
Suspicion has been heightened by the assumption that mass-media techniques contain the potential to influence and control the thoughts of the masses. Erich Fromm complains that television can be used "to build up political personalities as they use it to build up a soap; what matters is the effect, in sales or votes, not in the rationality or usefulness of what is presented." 57 Concern has been expressed over the possibility that mass-media skills have brought a "Brave New World" type of environment closer to fruition. Learned Hand, after making the comment that "the art of publicity is a black art," complained that it could be used to shape the individual's tastes, feelings and desires and "to torture and destroy .. . for an obscene faith, baseless in fact and morally monstrous." "ss

It would serve minimal purpose to expand upon the origins or to argue the pros and cons of the prevailing mood of misgiving that seems to be focused towards advertising. However, there is one observation that strikes at the core of the mass-media problem and in doing so provides an explanation for the difficulty that the judiciary is experiencing in relating the subject to antitrust. Almost universally mass media is analyzed and, of course, condemned on a fragmentary or atomistic basis-in terms of specific forms of communication, or in terms of occupational functions such as advertising, promotion, public relations, etc. On occasion the field has been classified in terms of the tangible (the informative function) and the intangible (the persuasive function). Unfortunately, classification ignores or at least clouds the institutional characteristics of mass media. ${ }^{59}$ Placed in proper perspective, it becomes difficult to argue with C. Wright Mills' observation that "the media have not only filtered into our experience of external realities, they have also entered into our very experience of our own selves." 60 Hence what was originally a by-product of emerging abundance and consumption now permeates our culture to the extent that it has become an institutional force.

Analyzing the mass-media problem on an atomistic basis has been a significant factor in some of the problems associated with product differentiation. Professor Bain contends that product differentiation

\footnotetext{
37 E. Fromi, The Sane Society 166 (1966) (Fawcett Premier ed. 1965).

38 Proceedings in Memory of Mr. Justice Brandeis, 317 U.S. IX. XV (1942). For a contra view see Barron, Access to the Press-A New First Amendment Right, 80 HARv. L. Rev. I64I, 1646 (1967).

s9 David Potter is the most outspoken exponent of the institutional characteristics of mass media. D. POTTER, supra note 54 , at 167.

${ }^{60}$ C. Mills, The Power Elite 314 (Galaxy ed. 1961).
} 
is attributable to a series of factors: "differences in the design . . . of competing products, by efforts ... to distinguish ... products through packaging, branding, and the offering of auxiliary services to buyers, and by advertising and sales promotional efforts . . . ."61 It would be extremely difficult to establish reliable and accurate means of ascertaining the contribution that any single factor might exert on the creation of strong consumer preferences. ${ }^{62}$ For example, how can the impact of packaging on consumer choice be ascertained? On one hand, a package merely serves as a container and is, of course, a mandatory expense item. Yet simultaneously it can be, and often is, an extension of the promotive and advertising process. ${ }^{63}$ The visual merges with the tactile so as to proliferate the product's image. Or, and this is undoubtedly the ultimate in packaging, the visual can be consumable. ${ }^{64}$ Another fragmentized part of product differentiation, branding, also poses a problem. Brand imagery can be residual in effect; once established in the consumer's psyche, it might require minimal effort in terms of expenditures to reinforce the image. ${ }^{65}$

The almost unanimous condemnation of mass-media-inspired product differentiation ${ }^{66}$ is predicated upon the notion that there exists a sharp and discernible line between conveying to the public an informational awareness and appreciation of the physical properties of the product, and inducing preferences predicated on nothing more than the incorporeals of wasteful, persuasive hyperbole. And "when heavy advertising and other promotional expenditures create durable preferences going beyond the relative superiority of the product, resistant to anything but major countervailing promotional

\footnotetext{
${ }^{a}$ J. BaIN. supra note 30 , at 114.

$\therefore$ A further obstacle to accurate measurement is suggested by Riesman's theory that the personality itself has become a product. And "there exists in the production of personality the same sort of 'product differentiation' that is characteristic of monopolistic competition . . ." D. RIESMAN, supra note 37, at 46. Efforts at personality differentiation, or what Riesman calls "marginal" differentiation, would necessarily have to be reflected in consumption decision making. But accuratc measurement of "marginal" differentiation is impossible.

"As one court put it, "with increasing standardization of products generally, consumer appeal through attractive packaging has become a developing aspect of competitive activity." Gerber Prods. Co.v. Beech-Nut Life Savers, Inc., 160 F. Supp. 916,922 (S.D.N.Y. 1958).

of TIME. Sept. 22, 1968, at 102.

"TIME. Feb. 9, 1968, at 90.

to Professor Dewey refuses to condemn product differentiation on "the conviction that economists qua economic theorists-as distinct from moral philosophers-have nothing to say about the social disutility of product differentiation.” D. DEwEY. MONOPOLY IN ECONOMICS AND LAW 98 (1966).
} 
campaigns, we may well question whether the price has not become too high." $" 67$

\section{EConomic Theory and the lnevitableness of Persuasive MASS MEDIA}

As long as perfect competition and a narrow abstracted view of monopoly served as theoretical models, economists generally ignored the problems of mass-media influences. Under perfect competition a large number of sellers marketed a standardized product which eliminated, at least theoretically, the need for the differentiation of products. Moreover, since many sellers compete, investment in advertising, no matter how large, would generate a negligible increase in total demand with a correspondingly infinitestimal increase in the advertisers' own sales figures. ${ }^{68}$ As for the monopolist, he already is in complete control of the market; advertising would be a superfluous gesture. This sweeping denial of mass-media influences ceased when the realism of monopolistic competition, workable competition, etc., revealed the hypothetical and abstract character of perfect competition $^{69}$ and pure monopoly. Economists, under the umbrella of oligopoly theory, have done more than merely recognize mass media as part of the economy, they have assumed its inevitableness.

A general awareness by the oligopolist of his competitors' range of possible and probable decision-making patterns and the ability quickly to counter any changes by rivals makes each oligopolist reluctant to engage in open, direct-and disasterous-price warfare. "Price reduction may seem profitable for a fortnight, but when the rival has followed suit, both may be worse off."" However, the oligopolist does not remain inactive. Price competition is replaced by efforts designed to lure customers away from rivals by the more cautious, less ostensible, and safer route of persuasive mass media."

In this setting the economist considers advertising a waste of resources. ${ }^{22}$ Assuming that all oligopolists have equal access to

\footnotetext{
${ }^{67}$ Turner, Advertising and Competition, 26 FED. B.J. 93, 94 (1966).

${ }^{68}$ E. Chamberlin, The Theory.of Monopolistic Competition 127 (8th ed. 1962). See also J. KuhlMan \& G. SKinner, The Economic System 142 (revi. ed. 1964).

${ }^{69}$ This is not to say that perfect competition has been completely discarded by the economist. See Bernhard, Competition in Law and Economics, 2 ANTitrust LaW \& Eco. REv. 1099, 1117 (1967).

${ }^{70} \mathrm{H}$. Brems, Product Equilibrium Under Monopolistic Competition 232 (1951).

" R. Caves, American Industry: Structure, Conduct, Performance 45 (2d ed. 1967).

12 "At the point where advertising departs from its function of informing and seeks to persuade or deceive us, it tends to become a waste of resources. The paper carrying brightly colored ads, the brains wracked to conjure up catchy slogans, would produce more net satisfaction in other uses." R. CAves, supra note 71, at 105.
} 
supporting financial resources, a uniform commitment to sales promotion can only result in a stand-off, thus precluding any single firm from permanently taking business from the competition. ${ }^{73}$ This cancelling-out effect is projected into the entire economy with the net result that over the long run no industry, or individual firm, gains ground at another's expense.

This perspective is an integral part of the structural analytics that has been absorbed by the Supreme Court. Advertising is inevitable and functionless. Economic theory thus provides justification for the harsh treatment of persuasive mass media. This view, however, reflects a dangerous oversimplification of the problem. It is inconsistent, on one hand, to posit that sales promotion and advertising can have a conclusive effect in shaping consumer decisionmaking, and then frame economic theory on the premise that the ultimate results of all this activity are rendered nugatory by a cancelling-out effect. The extensions of mass media are too persuasive not to leave an indelible mark on the totality of the economy.

Not all commentators have become entangled in this theoretical inconsistency. There is increasing awareness that in a society in which the emphasis is so strongly on consumption, consumer demand is a matter of national resource commitment. John Kenneth Galbraith, while condemning the public waste of advertising, concludes that persuasive mass media is essential to the perpetuation of a contemporary economic system which he, somewhat colorfully, has identified as the "technostructure." Mass media's assignment is to make sure that aggregate demand meets the preplanned goals of the technostructure. ${ }^{74}$ To Galbraith the technostructure "reaches forward to control its markets and on beyond to manage the market behavior and shape the social attitudes of those, ostensibly, that it serves." 75 Another economist suggests that the increasing prevalence of uninformed markets, the consequence of technological advances, leaves the consumer with no alternative other than to rely on advertising. ${ }^{76}$ Professor Backman, on the other hand, argues that

Economists do, however, acknowledge that not all advertising expenditures are wasted. $R$. Brandis, Economics: Principles and Policy 97, 100 (1963); T. Scitovsky, Welfare and COMPETITION 426 (1951).

"W. Carter \& IV. SNavely, INTermediate Economic Analysis 239 (1961).

"J. Galbraith, The New Industrial State 223 (1967).

"Id. at 212.

${ }^{76} \mathrm{~T}$. SCITOVSKY, supra note 72 , at 334. 
mass media endeavors are simply a dimension of the competition ethic, a means of getting a time advantage over rivals." Historian David Potter concludes that advertising serves to acquaint and adjust society to the imperatives of "a new set of drives and values in which consumption is paramount." ${ }^{\prime \prime}$ As far back as 1946 the Supreme Court recognized that the implications of sales promotion can transcend the immediacy and demands of the individual advertiser's market position. "[A]dvertising," said Mr. Justice Burton, "may benefit indirectly the entire industry, including the competitors of the advertisers." $"$ The Federal Trade Commission has, on at least one occasion, echoed Justice Burton's views on the capacity ol mass media to increase aggregate demand. Commenting on the cigarette industry as a whole the F.T.C. noted that "[m]assive advertising . . . appears to be a potent force in increasing sales of cigarettes . . . ." "su

The inevitability of mass media, and particularly that of persuasive advertising, is still part of the economic Weltanschaulung. However, the functionless and sterile inevitability that past theorists associated with mass media is beginning to recede into the stockpile of discarded economic theories. Value judgments that assume misallocation of resources and harmful effects on society can no longer obscure the presence and impact of mass media on the economic structure.

\section{Judicial Reaction to the Mass-Media Ethic}

A Supreme Court steeped in the habits and precedents of a behaviorist antitrust tradition has not had an easy time with mass media. This difficulty has been compounded by a lack of frontal case exposure to a phenomenon that has been a vital influence on the national character only since World War 11 . With one possible exception, ${ }^{81}$ cases having meaningful mass-media overtones date back no further than 1946. Nevertheless, a growing range of available case

"J. BACKMAN. supra note 48, at 3.

78 D. Potter, supra note 54, at 173.

${ }^{79}$ American Tobacco Co. v. United States, 328 U.S. 78 I, 797 (1946).

${ }^{80}$ Quoted in Blank, Some Comments on the Role of Advertising in the American EconomyA Plea for Revaluation. A. Barban \& C. Sandage, Readings in Advertising and PromoTION STRATEgy 5 (1968).

"In Sugar Institute, Inc. v. United States, 297 U.S. 553 (1936), the Supreme Court recognized the efficacy of advertising. "[C]ertain of the defendants had built up a preference for brand names sufficient before and after the Institute was organized to enable such brands to command a higher price than the sugar of the other defendants . . . " Id. at 572-73. 
commentary, covering at least four statutory areas, justifies a close scrutiny.

\section{A. Controlled Ambivalence}

It is only appropriate that the Robinson-Patman Act, which first introduced a marketing and consumption frame of reference into trade regulation,, 2 should graphically mirror the complexities of relating the shifting and expanding currents of mass media to a statutory vocabulary keyed to the problems of another era. In the depression-conscious mid-thirties, the implications of a mass media culture, dependent upon an economy able to support grand consumption, were too far in the future to be of immediate concern. The absence of foundational guidelines in this area has generated problems. Language directed towards the tangible and concrete market advantages of quantity purchasing power must now be interpreted in a totally new environmental setting. ${ }^{83}$ As a result of these environmental alterations the courts are now confronted with the increasingly complex problem of whether, or how, to maintain a balance between the coeval institutional forces of mass media and a Robinson-Patman Act norm that is embodied in a resolute commitment to the proposition that every effort should be made to reach the merits of the case. Consequently, care should be taken to avoid getting bogged down in what are considered to be irrelevant jurisdictional problems. In addition, once a finding is made, it should, so as to maintain the norm, be resistant to only the strongest attack. As a result of this type of norm development, the level of proof necessary to invoke the statutory defenses under the Act has been high.

Robinson-Patman norms have thus far proven resistant to massmedia pressures, particularly on the Supreme Court level. Consider the interpretation given the "like grade and quality" jurisdictional requirement of section 2(a) of the Act. ${ }^{84}$ So long as consumer

: See text accompanying note 18 supra.

* One reason for the difficulty in getting clear appraisal of the Robinson-Patman Act is, according to Corwin Edwards, the presence of "institutional trends as the growth of nationalbrand advertising, the development of supermarkets, the growth of the pre-packaging of foods, and the shift of demand from staples to specialties . . . C. EDwards, THE PRICl: Discrimination Law 617 (1959).

* Section 2(a) makes it unlawful "to discriminate in price between different purchasers of commodities ol like grade and quality ... . where the effect of such discrimination may be substantially to lessen competition or tend to create a monopoly in any line of commerce . . . ." I5 U.S.C. \$13(a) (1964). 
reaction, in terms of willingness to pay a given price, remains constant when chemically and physically identical products are involved, the situation is within the perimeter of inquiry originally envisioned by the drafters of the Act. It is a Borden ${ }^{85}$ set of circumstances that creates the dilemma. The Borden Company markets its "Silver Cow" brand of evaporated milk on a national basis. Conventional mass-media techniques have been employed to engender consumer preference for "Silver Cow." For some time Borden also packaged and sold the identical milk under privately-owned labels to regional wholsesalers at prices significantly below what it charged for its own national brand. The price differential and the variance in consumer reaction that prevailed at the retail level was clearly attributable to sustained and effective promotion, and therefore, so Borden argued in responding to charges of price discrimination, the milk was not, in the arena of the marketplace, of "like grade and quality."

In hurdling the jurisdictional requirement and getting at the merits, the Supreme Court had an option of two recognized interpretations. They could invoke a market-acceptability test and conclude that reification of the intangibles of mass media can occur. ${ }^{86}$ In effect, product metamorphosis takes place as a consequence of successful promotion; a heavily advertised product becomes "different" than a regional and less promoted item. ${ }^{87}$ The second alternative open to the Court was the strict physical-identity test. Are the products, in terms of chemical and physical analysis, equivalent?

Mr. Justice White, writing for a 7-2 majority, applied the physicalidentity test. However, he did not reject the reality and fait accompli of the mass-media contribution to the consumption equation. "Our holding neither ignores the economic realities of the marketplace nor denies that some labels will command a higher price than others ...." "88 To ignore "economic realities" would have been too inconsistent with the factual content of the record and with obvious

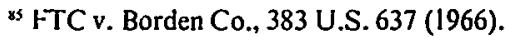

${ }^{8}$ Under the market-acceptance test "reliance is placed on consumer-buyer evaluation of the products in determining whether they should be considered alike or different." Cassady \& Grether, The Proper Interpretation of "Like Grade and Quality" Within the Meaning of Section 2(a) of the Robinson-Patman Act, 30 So. CAL. L. Rev. 241, 248 (1957).

${ }^{87}$ The product becomes different in terms of intangible qualities added and also in terms of a discernible physical difference that could result from quality control of the nationally advertised brand. Brief for Respondent at 4-5, FTC v. Borden Co., 383 U.S. 637 (1966); Cassady \& Grether, supra note 86, at 264. See also Learns, Borden Decision Spells Change-but Changes Already in Wind, ADVERTISING AGE, April 4, 1966, at 120.

${ }^{\text {s }} 383$ U.S. at 645.
} 
environmental pressures. ${ }^{89}$ Yet it is inescapable that to invoke the confining physical-identity test as a guide in section 2(a) jurisdictional analysis, as a matter of fact, does ignore the existence of new and significant media pressures that impinge on Robinson-Patman application. Perhaps recognizing this entanglement the Court passed the problem of "tangible consumer preferences as between branded and unbranded commodities [on to] the more flexible 'injury' and 'cost justification' provisions of the statute." 90

Viewed as an endeavor to adhere to norms, the apparent contradiction between the treatment given the premium-regular brand situation under "like grade and quality" with what it receives under section 2(b) disappears. ${ }^{91}$ Thus far a vendor of a nationally known brand is precluded from invoking the "good faith meeting of competition" proviso as a shield to price discrimination charges when he reduces his prices so as to disturb the "normal" differential between his product and a competing local or "regular" brand-even though both items are exactly identical.92 The rationale is that nationally advertised brands should bring a higher price than less promoted local brands. Hence the efficacy of mass media is expressly utilized so as to preserve a finding of price discrimination. ${ }^{93}$

The strain on coherent and symmetrical decisional ratiocination produced by adherence to a policy predicated on the thesis that the

s9 Mr. Justice Stewart, in dissenting, spelled out the "economic realities" in the following terms: "The product purchased by a consumer includes not only the chemical components that any competent laboratory can itemize, but also a host of commercial intangibles that distinguish the product in the marketplace. The premium paid for Borden brand milk reflects the consumer's awareness, promoted through advertising, that these commercial attributes are part and parcel of the premium product he is purchasing." 383 U.S. at 649-50.

\$0 383 U.S. at 646, citing AtToRney General's NATIONAL Committee to Study ANTIrRust LAws 159 (1955). The Committee noted that "in this way lby evaluating the "injury" and "cost" defenses in any preliminary investigation] a strict interpretation of the statutory phrase 'like grade and quality' can facilitate Federal Trade Commission enforcement while yielding realistic results in practice." $I d$.

The Committee was not in unanimous accord. A minority concluded that "a price discrimination law can consider heavily advertised and anonymous or private-brand mcrchandise on an equal footing only at a serious distortion of economic facts." Id. at 158.

${ }^{\prime \prime}$ Section 2(b) allows the seller to demonstrate that his "lower price . . . was made in good faith to meet an equally low priee of a competitor ..." 15 U.S.C. $\$$ 13(b) (1964).

${ }^{92}$ Callaway Mills Co. v. FTC, 362 F.2d 435 (5th Cir. 1966); Anheuser-Busch, Inc., 54 F.T.C. 277, 301-02 (1957); Minneapolis-Honeywell Regulator Co., 44 F.T.C. 351 (1948), rev'd on other grounds, 191 F.2d 786 (7th Cir. 1951), cert. denied, 344 U.S. 206 (1952).

93 The Fifth Circuit, in allowing the $\$ 2$ (b) defense, summarized the role that mass media plays in the following language: "Furthermore, the public is greatly influenced by such intangibles as color, design, display, advertising, and similar factors. So long as petitioners 
case be heard on its merits and that the resultant findings be preserved was made patent by the Borden case. Denying the efficacy of massmedia techniques when one part of the Act is under consideration, only to admit it under another section, is difficult to explain on the basis of "policy." Perhaps just as significant as this internal inconsistency is the fact that the Court manifested an entrenched distrust of the persuasive manifestations of advertising and of the manipulative potential thought to accompany promotion, all of which, so the Court reasoned, could be traced to the quantity of the advertising budget. Market acceptability "would obviously focus not on consumer preference as determinative of grade and quality but on who spent the advertising money that created the preference . . . ."9s Such an attitude should cast some doubt on a continuance of the section 2(b) distinction between premium and regular products. It is, however, more than likely that the fragile equilibrium will continue-the vague syntax of the Robinson-Patman Act (it has been called "one of the most tortuous legislative pronouncements ever to go on the statute books"), ${ }^{96}$ and a history of being interpreted in a resultoriented fashion, makes it something less than the ideal instrumentality through which to explore new areas.

\section{B. Objective Proof and the Mock-Up: The Medium is Not the Message}

By the definition established earlier in this article, mass media is also composed of technological characteristics. ${ }^{97}$ Three of the more significant technological instrumentalities, the printed word, the oral transmission properties of the radio, and television, are the most prevalent and effective conveyors of promotion and advertising. During the period of time in which virtually all major trade-regulation laws were enacted, the printed word and radio dominated the media

conclusively show that their products at various price levels generate public demand ... substantially equivalent to that of competitors' carpeting at the same price levels, considerations of 'grade and quality' become unnecessary ... . Callaway Mills Co. v. FTC, 362 F.2d 435, 441 (5th Cir. 1966). The impact of packaging on the consumer was recognized, but not considered sufficiently relevant to the fact situation at hand, in Gerber Prods. Co. v. Beech-Nut Life Savers, 160 F.Supp. 916, 922 (S.D.N.Y. 1958).

"See Austin, Product Identity and Branding Under the Robinson-Patman Act: Is the FTC"s Approach Consistent with the Realities of the Marketplace? 12 VILL. L. REv. 251 (1967).

383 U.S. at 645 n.6.

* J. Dirlan \& A. Kahn, Fair Conpetition: The Law and ḱcononics of antitrust Policy 119 (1954).

${ }^{97}$ See note 2 supra and accompanying text. 
scene. Television is essentially a post World War II pheonomenon, ${ }^{98}$ with a life span that roughly parallels that of the age of consumption.

Although print and radio evoke different perception faculties (visual and hearing, respectively), the transmission in both cases is constant. The message composed at the point of origin does not change form during its voyage to the public." This is not true of television, where the viewer utilizes both hearing and visual sense responses. In TV, the visual element involves movement. ${ }^{100}$ However, of greater implication is the three-stage materialization of images: point of origin, viewer reception, and resultant effect on viewer behavior. Frequently, a conversion or alteration in depiction occurs between the transmission point of origin and stage two-the point of viewer reception. The problem indigenous to $\mathrm{TV}$ is the manner of recognition and the treatment to be given depiction alteration. Very much a part of this problem (and still unresolved) is the effect that the dual sensory combination, with the concomitant movement on the screen, has on viewer behavior - the third stage in the materialization of image process.

Within the context of trade regulation the Supreme Court has so far avoided a head-on analysis of the problems posed by television's transmissional variations. In FTC v. Colgate-Palmolive Co., ${ }^{101}$ a oneminute TV commercial depicted the shaving of sandpaper allegedly made possible by the softening properties of Colgate-Palmolive's "Rapid Shave." Since transmission impulses would have given the viewer the impression that real sandpaper was "nothing more than plain, colored paper," 102 plexiglass with sand attached was used. The

\footnotetext{
s8 In 1948, 17 stations were operating; by 1959 the number was up to 562 . Television homes increased from $1,600,000$ in 1949 , to $45,200,000$ in 1960. A. Frity. Advirtising 25I (3d ed. 1961).

$"$ There is, however, a variance in exposure opportunity between the two mediums. A. FritY. supra note 98 , at 250.

"wew McLun contends that television is a "cool" medium while radio is "hot." "Hot media are... low in participation, and cool media are high in participation or completion by the audience. Naturally, therefore a hot medium like radio has very diflerent effects on the user from a cool medium like the television." M. Mcluhan, Understanding Media: The Extensions OF MAN 36 (Signet ed. 1964). Media also have been classilied in terms of "indicated" reader interest (newspaper, radio and TV) which requires some form of action by the reader in obtaining exposure opportunity, and "optional" reader interest (outdoor posters) which might or might not be read but which requires no action for exposure. A third classification catalogues radio and TV as "dynamic," the consumer must act to avoid exposure, and newspapers and magazines as "static," where the consumer must act in order to absorb the message. A. FREY, supra note 98 , at 236-37.

IUI 380 U.S. 374 (1965).

102 Id. at 377 .
} 
technological character of the medium prevented consistency of transmission; thus, in order to make sure that the desired image was received by the viewing public, the advertiser used "mock-ups" at the transmission point of origin.

The Federal Trade Commission complained that viewers were given the impression that they were actually seeing a demonstration of a razor gliding across Rapid Shave moisturized sandpaper. To the Commission this constituted a deceptive trade practice ${ }^{103}$ even though the "advertiser has himself conducted a test ... or demonstration which he honestly believes will prove" will, as a matter of fact, moisturize sandpaper. Despite the definitive manner in which the television transmission problem was presented, the Court expressly refused to get entangled in a discussion of the technological barriers that reside in the communication process of the medium. The FTC's holding was upheld..$^{105}$ What the viewer would perceive if he were at the point of transmission origin must objectively and in every respect coincide with what actually appears at the point of viewer reception. It was a rather mechnical treatment; there was no departure from the precedent of the verbal and print misrepresentation cases. ${ }^{106}$ The use of mock-ups was analogized to a seller making false claims of celebrity testimonials and untrue allegations of "certified" product tests. Verbal allegations and image representations must, so the Court concluded, reflect the sameness in terms of tangible reality for all parties-the vendor, the purchaser and the public-and, furthermore, this sameness must prevail at both point of transmission and at the point of reception. ${ }^{107}$

103 "Unfair methods of competition in commerce, and unfair or deceptive acts or practices in commerce, are declared unlawful." 15 U.S.C. $\$ 45(a)(1)$ (1964). See generally Developments in the Law-Deceptive Advertising, 80 HARV. L. REv. 1005 (1967).

ior 380 U.S. at $385-86$.

${ }^{105}$ Colgate did not contest the court of appeals' holding that the speed with which Rapid Shavc could shave sandpaper had been misrepresented as one minute, the length of the commercial, when it actually took 80 minutes.

106 "Respondents claim that all these cases are irrelevant ... because they involve misrepresentations related to the product itself and not merely to the manner in which an advertising message is communicated. This distinction misses the mark for two reasons. In the firsti place, the present case is not concerned with a mode of communication, but with a misrepresentation that viewers have objective proof of a seller's product claim over and above the seller's word. Secondly, all of the above cases, like the present case, deal with methods designed to get a consumer to purchase a product, not with whether the product, when purchased, will perform up to expectations." 380 U.S. at 388.

${ }^{107}$ The dissent of Justice Harlan recognized the defects in such a view. "The faulty prop in the Court's reasoning is that it focuses entirely on what is taking place in the studio rather than on 
The relevance of the FTC $v$. Colgate-Palmolive opinion is that a medium born in and of the age of consumption is seen as relating to the public in exactly the same manner as the more established methods of communication. The real issue, correctly perceived by the dissent as "what techniques the advertiser may use to convey essential truth to the television viewer," 108 was disregarded. Rather than framing a solution on the basis of the technical characteristics of a relatively new form of media, the Court dwelled on television's "limitations." 109 The immediate and perhaps intended effect of this view is to dilute the technological range of an important mass-media instrumentality. The burden is on the "ingenious advertising world" confine their presentations to the well-defined and concrete transmission patterns of the stereotyped and familiar oral and print media. ${ }^{11}$

Given the present state of knowledge it would have been appropriate for the Court to resolve this type of case on a flexible, particularistic basis, focusing on specific product-transmission problems. Certainly a commitment to a mechnical-consistency-oftransmission rule is not appropriate.

The Colgate-Palmolive decision has additional implications. The relationship between commercial television and the advertising industry has been the subject of intense criticism. The "vast wasteland" of programs appearing on the TV screens is usually attributed to the dictates of Madison Avenue. Colgate-Palmolive leaves the distinct impression that a concern with the wiles of an "ingenious advertising world" and its assumed influence over television has served to block appreciation of the medium's unique problems. ${ }^{112}$

\section{Goodwill and Rational Deliberation}

Goodwill is one of the prime objectives of the advertising and

what the viewer is seeing on his screen. That which the viewer sees with his own eyes is not, however, what is taking place in the studio, but an electronic image." 380 U.S. at 396.

For a summary of the possible effects of the majority's view see Note, Illusion or Deception:

The Use of "Props" and "Mock-Ups" in Television Advertising, 72 YALE L.J. 147, 155 (1962).

lox 380 U.S. at 395.

105 Id. at 391 .

"Id. at 390.

"' It is interesting to note that the advent of radio also posed problems of accommodating old message forms to a new medium. R. Hower, THE History OF AN ADVERTISING AgENCY 167 (1939).

1'2 Perhaps, as one commentator has suggested, the Court felt that television is too persuasive. G. AleXANDer, Honesty And CoMpetition 208 (1967). 
promotion process. Roughly speaking, it can be defined as a consistently favorable consumer reaction to carefully selected stimuli, including brand name and symbol, all of which are made part of the public scene via mass-media techniques. ${ }^{13}$ Fair trade statutes corporealize and then protect goodwill. However, fair trade laws, or more specifically the enabling Miller-Tydings ${ }^{114}$ and McGuire Acts, ${ }^{115}$ represent the only area in the trade-regulation enclave in which goodwill receives statutory protection. ${ }^{116}$

As goodwill increases in scope and success, there is a parallel growth in concern by the vendor as to whether his product will be properly utilized and maintained. ${ }^{117} \mathrm{~A}$ familiar means of protecting the investment in goodwill is to dictate when ancillary products are to be used in conjunction with the principal product. The justification usually asserted for the tie-in is that it prevents the consuming public from becoming disenchanted because of malfunctions that might result from the use of inferior secondary parts. ${ }^{118}$

The cross-market leverage consequences of the tying arrangement bar wide acceptance of the goodwill defense. The Supreme Court has never accepted it, reasoning that the vendor can adequately maintain his reputation by specifying to his customers the type and quality of the ancillary article that will assure efficient functioning of the primary product. ${ }^{119}$ The customer's freedom to make his own choice is thus maintained. And "if the manufacturer's brand of the tied product is in fact superior to that of competitors, the buyer will presumably choose it anyway." 120 The assumption is that the customer will select the secondary item after rational deliberation and

${ }^{113}$ See C. Kaysen \& D. Turner, Antitrust Policy 74 (1965). See also E. Brink \& W. Kelley, The Management of Promotion 76-77 (1963).

1115 U.S.C. $\& 1$ (1964).

is Id. \& 45.

116 The theory is, so said the Supreme Court in interpreting an Illinois Fair Trade Act, "that the sale of identical goods at less than the price fixed by the owner of the mark or brand is an assault upon good will . . . ." Old Deaborn Distrib. Co. v. Seagram-Distillers Corp., 299 U.S. 183,195 (1936).

13 See E. BRINK \& W. KelLeY, supra note 113, at 294.

118 "But the manufacturer not only gave express warranties for a period to the dealers' customers, but it was shown that the replacement parts were generally not supplies consumed in operation, but operating parts of a complex mechanism, the origin of which is inevitably attributed to the manufacturer, and the failure of which is inevitably placed at his door, with resulting impairment of good will and damage to the reputation of his product." Oxford Varnish Corp. v. Ault \& Wiborg Corp., 83 F.2d 764, 767 (6th Cir. 1936).

119 Standard Oil Co. v. United States, 337 U.S. 293 (1949).

${ }^{120}$ Id. at 306. 
after carefully investigating the functional capabilities of competing products. The superior product will prevail. Complete reliance is placed on the effectiveness of informational advertising and the existence of a rational consumer ${ }^{121}$ who is presumably immune to the blandishments of mass media. ${ }^{122}$ In other words, as far as the tying arrangement is concerned, the Supreme Court refuses to recognize the role of persuasive promotion in the formation of purchasing decisions. ${ }^{123}$

\section{FTC v. Procter and Gamble: Persuasion Quantification and Barriers to Entry}

It is, however, when designated as a causative force in the erection of barriers to market entry and as a factor in product differentiation, that mass media receives its most expansive recognition. Moreover, the emphasis on these two elements of structural analytics has increased significantly with the growing trend of firms establishing cross-market relationships-usually taking the form of conglomerate acquisitions or complimentary product extensions. ${ }^{124}$ A question yet unanswered, but certainly raised in FTC v. Procter and Gamble $C o .{ }^{125}$ is whether mass media is to be retained as part of the productdifferentiation norm, or whether it is emerging as a pressure form in itself, and operating in a sufficiently distortive fashion on structural formations as to deserve outright proscription.

The acquisition of Clorox by Procter \& Gamble produced an environment that was particularly suited to the mass-media technique. Clorox dominated an oligopolistic industry, as did Procter \&

\footnotetext{
${ }^{\text {"2I }}$ Reliance on the "rational consumer" can pose problems. Because of a strong mechanical relationship between its glass-lined silos and unloading devices defendant usually "tied" the latter to the former. When individual sales of loaders were made, purchasers were clearly warned of the dangers of not using them in conjunction with defendant's silos. "[I n spite of defendants educational efforts" 18 of 36 customers filed complaints. Dehydrating Process Co. v. A.O. Smith Corp., 292 F.2d 653, 656 (Ist Cir. 1961).

${ }^{122}$ As a matter of fact, the inability of the consumer to make valid product comparisons in the face of mass-media pressures is attracting growing attention. See 1967 ANTITRUST LaW Symposium (N.Y. State Bar Ass'n, Trade Reg. Rep. ed.); Barber, Government and the Consumer, 64 Mich. L. Rev. 1203 (1966).

${ }^{123}$ Lower federal courts have not been as harsh on the goodwill defense as the Supreme Court. See Susser v. Carvel Corp., 332 F.2d 505 (2d Cir. 1964); Pick Mfg. Co. v. General Motors Corp., 80 F.2d 641 (7th Cir, 1935).

${ }^{124}$ See generally Turner, Conglomerate Mergers and Section 7 of the Clayton Act, 78 HarV. L. Rev. 1313 (1965).

123 386 U.S. 568 (1967).
} 
Gamble. ${ }^{126}$ The relevant line of commerce, liquid household bleach manufactured by Clorox, is a fast-turnover presold consumer product which is marketed through supermarkets and grocery stores. All household bleach has basically the same chemical composition. The products were complimentary, thus "products of both parties to the merger are sold to the same customers, at the same stores, and by the same merchandising methods . . . ."127 The cumulative effect of these factors was to make the disciplined use of advertising and promotion the chief, or perhaps the only, differentiating weapon in maintaining or expanding market control.

Central to a finding by the Court that the acquisition did result in the creation of substantial barriers to entry was express recognition of the capacity of advertising to "guide" consumer-product selection. The tone of the Supreme Court's recognition of mass-media exertions was much more complete and definitive than heretofore decisions had provided. In direct fashion, the Court concluded that the relevance of advertising to market control and expansion can, in a conducive setting, be so powerful as to subdue completely the more traditional sales determinants, such as price and quality.

Broad recognition of mass-media pressures did not, however, solve the pragmatic problem of accurately determining when or the extent to which mass media can generate changes in a market structure. The Court's approach to this phase of the problem followed basic economic theory. The broad circumference of actual and potential influence on consumer choice that flows from mass media and its pronounced associational tendencies were sifted through a quantification filter. The residue-the expenditure figures of the budget-constitute the method of measurement. "[H]eavy [advertising and promotional] expenditures went far to explain why Clorox maintained so high a market share despite the fact that its brand, though chemically indistinguishable from rival brands, retailed for a price equal to or . . . higher than its competitors." 128 And an awareness of the immensity of Procter \& Gamble's advertising budget would deter, so the Court reasoned, potential competitors from entering the household liquid bleach industry. ${ }^{129}$

\footnotetext{
${ }^{126}$ Procter accounted for $54.4 \%$ of packaged detergent sales, and, along with ColgatePalmolive and Lever Brothers, controlled $80 \%$ of the market.

${ }^{122} 386$ U.S. at 574.

${ }^{128}$ Id. at 572.

139 The Court noted that in 1957, the year of the acquisition, "Procter was the nation's largest advertiser, spending more than $\$ 80,000,000$ on advertising and an additional $\$ 47,000,000$ on
} 
The general thrust of the Court's reasoning is keyed to the standard product differentiation interpretation. Yet, in spite of the attractiveness of an approach which is consistent with treatise explication, one can discern two assertive vibrations surfacing from FTC v. Procter \& Gamble. For one thing, there was an almost imperceptible shift, cloaked in a concern over possible advertising economies, from the usual atomistic approach to mass media. Advertising, exploited through the usual outlets, plus the use of promotional give-aways, plus the advantageous use of shelf space, were lumped together and considered in terms of the totality of their effect on the consumer and on competition. Although they did not engage in analysis of some of the more subtle and difficult problems encountered in exploiting and integrating the commercial into television programming so as to achieve maximum effect, an endeavor that the government did undertake in their brief, ${ }^{130}$ the Court did recognize the existence of interrelationships among mass-media techniques and the manner in which they reinforce each other. ${ }^{131}$

Yet any possible salutary impression created by a more contemporary treatment of mass media was neutralized by a second and more significant decisional vibration. The implication abounds that mass-media efforts oriented toward persuasion can reach a detrimental level of saturation and have such adverse competitive effects as to result in a form of market conduct that deserves

sales promotion." Id. at 573. In 1966 Procter spent $\$ 100$ million on network television. BUSINESS IVEEK, April 8, 1967, at 75.

130 "For example, television commercials are generally believed to be more effective when delivercd during a program than when delivered between programs. The advertising message is reinforced in the viewers' mind if it is associated with a favorite program. Moreover, the viewer is apt to be least attentive between programs. As a single product firm of modest size, Clorox beiore the merger did not, and doubtless could ill afford to, buy entire network programs." Brief for the Federal Trade Commission, at 42, FTC v. Procter \& Gamble, 386 U.S. 568 (1967). Procter disputed the Government's contention that liquid bleach had been, or would be, advertised on prime-time television programs. Brief for the Respondent, at 37-38, FTC v. Procter \& Gamble, 386 U.S. 568 (1967). Some of the advantages of the large advcrtiser have been minimized by "scatter planning - the purchase of short commercial time spots on a variety of shows on different networks . . . ." Thus "smaller advertisers who have found it uneconomic to foot the bill for full or participating sponsorship of a regular show" are turning to this method. So is Procter \& Gamble. Business Week, April 8, 1967, at 75.

13' Shortly thereafter the Third Circuit followed the broadened perspective of the Procter \& Gamble case. General Foods, one of the nation's largest producers and distributors of packaged foods, acquired S.O.S., a producer of household steel wool. In discussing the impact of G.F.'s advertising policy, the Court noted: "Advertising, according to G.F., embraces all phases of commcrcial communication with consumers, and all of the many consumer 'deals' and ' incentives." General Foods Corp. v. FTC, 386 F.2d 936, 938 n.3 (3d Cir. 1967). 
condemnation in its own right. Advertising leverage supplies the seller with a power over prices unrelated to the intrinsic merits of the product. ${ }^{132}$ The tone of Douglas' opinion leaves the impression that to eradicate this unhealthy form of leverage, he would proscribe advertising and promotional "conduct" in order to precipitate the return to a more competitive equilibrium for all firms in the market. The legacy of the early antitrust perspective hangs heavy over such a mass-media-conduct interpretation. ${ }^{133}$

\section{E. Mass Media as a Decisive Factor in Product "End Use" Competition}

The attention focused on the role of persuasive advertising in differentiating chemically and physically identical products tends to overshadow a reverse side of the problem. Media activity can make ostensibly dissimilar products competitive. As a result of advertising stimulation, articles that are clearly distinguishable as to design, chemical content and other features become to the public, interchangeable as to end use. The antitrust significance of this influence on cross-elasticity of demand is that mass media can play a crucial role in the determination of the relevant product market. It can also be crucial to structural analytics, which depends upon a clear definition of industry boundaries. ${ }^{134}$ The persistent inter-industry clash between the manufacturers of metal, glass, and plastic containers is, for two reasons, an excellent study of this effect. First the combatants have utilized the most modern and advanced advertising methodologies. Secondly, the Supreme Court has acknowledged the relevance of these factors in shaping cross-elasticity of demand.

In United States v. Continental Can Co., ${ }^{135}$ Mr. Justice White attributed shifts in preference between glass and metal contained baby

\footnotetext{
${ }^{132}$ By expressly excluding economies as a defense, 386 U.S. at 580, Douglas implicitly adopted the Commission's view that in its persuasive role, advertising has no social function and therefore deserves proscription.

${ }^{133}$ The Procter and Gamble conduct-oriented approach found expression in General Foods Corp. v. FTC. Although relating product differentiation to condition of entry and potential competition, as Douglas did in Procter, the basic complaint against the merger was the raw persuasive mass-media power exerted by G.F. General Foods Corp. v. FTC, 386 F.2d 936, 945 (3d Cir. 1967).

${ }^{134}$ See R. Caves, American Industry: Structure, Conduct, Performance 6-7 (2d ed. 1967).

135 378 U.S. 441 (1964).
} 
food to advertising and relegated price, usually considered to be the most persuasive influence in end use inter-changeability, to a secondary role. In endeavoring to regain lost ground in the baby food market, manufacturers of metal containers went to the core of the sales problem-the psychological quirks of the consumer. In-depth market research surveys were used to provide the necessary insights so that advertising campaigns could be developed that would "overcome mother's prejudice against metal containers." ${ }^{136}$ The success of these efforts, labeled "other competitive stimuli" 137 by the Court, reduced price and intrinsic product superiority ${ }^{138}$ to a secondary role in delineating the area of effective competition between glass and metal containers.

Budgetary statistics, as a barometer of advertising success, were ignored. The Court instead took what amounts to judicial notice of the efficacy of mass media. Moreover, there was no express or implied condemnation of the methods used to motivate consumer preference. Quite the contrary, the results of advertising activity were described as creating "meaningful competition between interchangeable containers." "139 Unquestionably, policy goals directed the course of the decision. Faced with what was considered to be "a merger . . . of such a size as to be inherently suspect," 140 the Court proceeded to a proscriptive conclusion-despite the fact that during the journey certain public benefits from mass-media efforts were recognized. ${ }^{141}$

\section{F. Advertising Economies as Justification for Suspected Conduct}

The dominant role that mass media plays in directing the trend of commercial success is reflected by the fact that business relationships are frequently formed for the express purpose of making possible the most efficacious uses of advertising and promotion. Upon antitrust attack it is not infrequent that an endeavor is made to shield the

\footnotetext{
${ }^{136} \mathrm{Id}$. at 451 .

137 Id. at 455 .

138 "Consumer preferences for glass or metal are often regional and traceable to factors other than the intrinsic superiority of the preferred container. For example, the one way beer bottle was highly successful in Baltimore-due in part to the efforts of "a highly motivated leading brewer'-but failed to make headway in Detroit." Id. at 453 n.6.

${ }^{139} \mathrm{Id}$. at 456.

${ }^{140} I d$. at 458.

14 Another possible way in which mass-media pressures, manifested through consumer preferences, can be recognized in product-relevant market ascertainment is by being read into the "peculiar characteristics" doctrine developed in the United States v. DuPont, 353 U.S. 586 (1957), case.
} 
relationship on the grounds that it engenders economies and efficiencies that are not only advantageous on a private basis (allowing the firm to be more competitive) but are also in the best interests of the public (the consumer getting higher quality products at lower prices). Where, however, the conduct is merger and it concludes with mass-media advantages, the talismanic ring of economies and efficiency go unheeded. ${ }^{142}$ Even when practiced individually, both forms of activity are almost automatically suspect. Chance of acceptance within the trade regulation framework is obviously reduced when merger and advertising are utilized in sequence. Justice Douglas ended any speculation on this point in Procter \& Gamble when he said, apparently speaking of advertising, "possible economies cannot be used as a defense to illegality." ${ }^{143}$

It might be argued that any economies, regardless of where manifested, could not have saved the Procter-Clorox merger. Yet Procter \& Gamble leaves the strong impression that advertising economies are not "acceptable" economies-or, as Justice Harlan complained, "advertising economies were placed in a different classification ...."144 Inherent in this view is the conclusion that mass-media savings are not passed on to the public. ${ }^{145}$

The views of Donald Turner, present head of the Antitrust Division, are not so emphatic as those of Justice Douglas. He is, however, not overly receptive to promotional economies. In a 1965 discussion of conglomerate mergers, Mr. Turner stated that there is "some argument for treating economies in promotional expenditures less favorably than other economies . ..." Nevertheless, his conclusion leaves the question open: a balancing "of various economic and legal considerations . . . suggests that perhaps there should be no discrimination when and if promotional efficiencies are allowed as a defense." 147

142 The relationship between firm size, market structure and efficiency remains the subject of hot dispute and conflicting views. See G. Hale \& R. Hale, Market Power: Size and Silape UNDER THE Sherman ACr 142-143 (1962), and citations collected in footnotes 16, 17.

143386 U.S. at 580.

is Id. at 603 (concurring opinion).

${ }^{145}$ The Government argued that while "advantages afforded by a merger which reflect simply greater efficiency ought not to be a basis for holding the merger illegal; efficiency is, after all, a prime goal of antitrust," the savings would not be passed on to the consumer. "It seems more likely that any such 'savings' would simply be used to obtain greater advertising of the Clorox brand than Clorox would afford before the merger." Brief for the Federal Trade Commission, at 47, 48, FTC v. Procter \& Gamble Co., 386 U.S. 568 (1967).

${ }^{146}$ Turner, supra note 146 , at 1339.

${ }^{147}$ Id. 
A balancing-of-competing-interests perspective is compatible with economic reality. If advertising economies operate to improve market structure they should furnish added weight to the defendant's position. The exoneration of a portion of the defendant's franchise system in United States v. Arnold, Schwinn \& Co. ${ }^{148}$ supports this view. Noting that the franchise arrangements had been inaugurated as a defensive measure against the expanding encroachments from competing mass distributors ${ }^{149}$ and that it was subsequently effective in allowing Schwinn to reap "a greater return from its advertising and. promotional expenditures," 150 the Court upheld the territorial consignment part of the program.

However, a certain amount of caution is appropriate. For one thing, it is apparent that the Court was dealing with advertising economies in only a peripheral way. Secondly, in the Arnold, Schwinn $\& C o$. situation the franchise system and the concomitant mass-media advantages were used to combat competitors who possessed even greater advertising advantages. Hence, the most that can be concluded is that advertising economies of minimal proportions may possibly be considered as a relevant factor in justifying questionable conduct when the combined effect of both activities is to create a more flexible market structure. ${ }^{151}$

\section{G. The Role of Mass Media in Franchise Arrangements}

There is still another view of the franchise-advertising sequence. Mass media usually plays the dominant role in determining the success, effectiveness, and the manner in which the franchise functions

\footnotetext{
148 388 U.S. 365 (1967).

149 "Schwinn adopted the challenged distribution programs in a competitive situation dominated by mass merchandisers which command access to large-scale advertising and promotion, choice of retail outlets, both owned and franchised, and adequate sources of supply." United States v. Arnold, Schwinn \& Co., 388 U.S. 365, 380 (1967).

${ }^{150} \mathrm{Id}$. at 384 (Stewart, J., concurring in part and dissenting in part). Advertising economies as justification for franchising was first raised by Justice Brennan in White Motor Co. v. United States, 372 U.S. 253, 269 (1963) (concurring opinion). Co-operative advertising advantages resulting from a trade association were called "beneficial to the industry and to consumers . . ." by Mr. Justice Stone in Maple Flooring Mfrs. Ass'n v. United States, 268 U.S. 563, 566 (1925).

${ }^{131}$ Consolidated Foods is another case where advertising power possessed by firms other than the defendant has been a factor. Where the defendant was accused of exerting illegal reciprocal trading pressures against various purchascrs, Justice Stewart concluded that those firms, such as Armour and Swift, who had "built significant brand names commanding consumer acceptance of their products" were immune to coercion. Because of the strong and entrenched brand acceptance of the Armour and Swift products the defendants' "economic power over this class is minimal." FTC v. Consolidated Foods, 380 U.S. 592, 607 (1963) (concurring opinion).
} 
in the marketplace. This is true both in terms of the manufacturerdealer relationship and the impact that the arrangement has on the consuming public. The franchise is, in effect, a mass-media instrumentality with three general purposes: one, it is a product differentiation booster, ${ }^{152}$ two, it can be used as a control device to protect goodwill-the manufacturer's "goodwill may be impaired if the brand is marketed to the consuming public by dishonest or disreputable merchants or if the consumer is unable to obtain prompt and adequate servicing of the product;"'s3 three, the franchise might be used as a means for attaining possible economies and uniformity of merchandising. ${ }^{154}$

Nowhere have media pressures played a more significant role than in the automobile franchise. As far as the consumer is concerned, the dealer's position as an independent sales entity has been totally effaced by the manufacturer's advertising (and ironically, by the dealer's own advertising). The automobile, with its ever changing design, the emphasis on warranties, and an accompanying barrage of sales impulses, all converge into a single image that the consumer associates with the manufacturer. Moreover, the premises of the franchised dealer, by its geographic location, its very presence and ancillary services, constitutes a highly effective vehicle for conveying the manufacturer's image to the public at large. ${ }^{155}$ As a result of these factors the dealer is thought of as merely a sales instrumentality or as an intermediary in the chain of distribution. "[T]he dealer, in the eyes of the public, represents the manufacturer, and to a large extent the goodwill of the manufacturer is in the hands of the dealer."156 From this type of arrangement it naturally follows that the risk of blame for product malfunctioning falls upon the manufacturer.

\footnotetext{
${ }^{152}$ R. CAVES, supra note 134 , at 22.

${ }^{133}$ Brief for appellant at 27, United States v. Arnold, Schwinn \& Co., 388 U.S. 365 (1967).

${ }^{134}$ Professor Preston notes that one of the four basic motives for the use of restrictive marketing arrangements is " $[1 /$ o determine quality and character of distributor service and to achieve other merchandising ends. In order to engage in brand name promotional activity on a continuing market-wide scale, a supplier may wish to obtain both specific character and quality and a considerable degree of uniformity in the operations of its distributors, including not only pre-sales service but also post-sales and replacement responsibility, ancillary merchandising activity (e.g., local advertising), and so forth." Preston, Restrictive Distribution Arrangements: Economic Analysis and Public Policy Standards, 30 LaW \& Contemp. Prob. 506, 511 (1965).

135 See note 152 supra. See also M. DeChazeau \& A. Kahn, INTEgRation and COMPetition in the Petroleum Industry 370 (1959); B. Pashigian, The Distribution of Automobiles, AN ECONomic ANalysis of THE Franchise System 38 (1961).

${ }^{136}$ Jordon, Exclusive and Restricted Sales Areas Under the Antitrust Laws, 9 U.C.L.A.L. Rev. 111, 123 (1962).
} 
One consequence of the franchise image that pervades the auto industry is that courts below the Supreme Court level have manifested a tendency to strike a balance in favor of the producer when goodwill is at stake. For example, possible impairment of goodwill has been a crucial factor in the lack of success in prosecuting tie-in allegations against automobile manufacturers. The Seventh Circuit set the tone in 1935 by upholding a plan whereby dealers, in order to obtain the right to sell Chevrolet cars, were required to use only General Motors parts for repair and replacement purposes. ${ }^{157}$ The court, after noting that the tie-in clause protected GM "against the otherwise possible use of defective parts in repairing or making replacements in their products," 158 keyed in on the goodwill implications. "The preservation of the goodwill of the public is directly involved." 159

While the Supreme Court has apparently discounted the goodwill defense in the tie-in situation (predicated on the existence of the "rational consumer"), ${ }^{160}$ lower federal courts continue to invoke the 1935 Pick rationale-restricting it to automobile franchise cases. ${ }^{161}$ However, there is evidence that some members of the Supreme Court (and perhaps the Justice Department) ${ }^{162}$ are cognizant that advertising and promotion designed to pre-sell have extended the producer's sphere of interest in the methods and conditions surrounding the distribution of his product. ${ }^{163}$

${ }^{\text {is }}$ Pick Mfg. Co. v. General Motors Corp., 80 F.2d 641 (7th Cir. 1935). The action was brought by an auto-parts competitor of G.M.

ist Id. at 643.

${ }^{159}$ Id.

160 "The justification most often advanced in their defense-the protection of the good will of the manufacturer of the tying device-fails in the usual situation because specification of the type and quality of the product to be used in connection with the tying device is protection enough." Standard Oil Co. v. United States, 337 U.S. 293, 306 (1949). See text accompanying note 121 supra.

${ }^{161}$ Nelligan v. Ford Motor Co., 262 F.2d 556 (4th Cir. 1959); Miller Motors v. Ford Motor Co., 252 F.2d 441 (4th Cir. 1958). Both of these cases involved advertising funds-LincoinMercury Dealers Advertising Funds-to which dealers were required to contribute. Both plaintiffs alleged that they were forced to contribute to these funds in order to retain the franchise. Among other things the Fourth Circuit acknowledgcd that "the advertising of Lincoln and Mercury automobiles has a most important bearing on the good will of defendant and its line of cars." Nelligan v. Ford Motor Co., supra at 558. In the Miller case the court noted that "the LMDA plan differs little from any other cooperative advertising plan, which, in the words of Mr. Justice Stone, is "admittedly beneficial to the industry and to consumers . . . " Miller Motors v. Ford Motor Co., supra at 447.

${ }^{162}$ The government conceded in the Schwinn case that the protection of goodwill might justify the imposition of restrictive marketing policies. Brief for the United States, at 27, 44, United States v. Arnold, Schwinn \& Co., 388 U.S. 365 (1967).

163 "Centuries ago," Mr. Justice Stewart said in United States v. Arnold, Schwinn \& Co., 388 


\section{Summary and Concluding ANalysis}

The weight and the influences of mass media are entering the mainstream of trade regulation cognition with increasing velocity and effect. ${ }^{164}$ Recognition has thus far been tentative, on an after-thought basis, and in some cases, contradictory. Effort is made to strain out as much of the intangibles as possible, thereby avoiding direct confrontation with sociological and psychological imponderables, or, for that matter, any element of the consumption ethic that does not lend itself to concrete apprehension. One result has been that analysis is conducted on a fragmentary basis. The effects of branding, the variance in consumer reaction caused by premium and regular products, the "deceptiveness" of the TV mock-up, and the goodwill features of the franchise, have each been splintered from the massmedia institution and then classified and analyzed in terms of the appropriate statutory niche. An endeavor is made to examine each media problem in terms of established principles and then to contour conclusions into the established boundaries of familiar antitrust goals.

The confined and narrow perspective of norm adherence and classification precludes an interpretation consistent with the realities of the contemporary environment. Moreover, even internal consistency within the individual opinions cannot be achieved. The courts are put in the position of recognizing and injecting the market consequences of advertising into section 2(b) of the Robinson-Patman Act while simultaneously, under section 2(a) of the same Act, holding these identical forces to be irrelevant. Overall decisional consistency has not been attained. When the tying arrangement receives Supreme

U.S. at 392, "it could perhaps be assumed that a manufacturer had no legitimate interest in what happened to his products once he had sold them to a niddle-man and they had started their way down the channel of distribution. But this assumption no longer holds true in a day of sophisticated marketing policies, mass advertising, and vertically integrated manufacturer distributions."

${ }^{16}$ The consequences of mass-media pressures have not been restricted to the antitrust area. For example, privity of contract, which long operated to shield the manufacturer from breach of warranty claims by those not within a direct contractual relationship, has been significantly emasculated as a direct result of contemporary mass-media pressures. As far back as 1934 a Washington court anticipated this shift: "Methods of doing business have undergone a great transition. Radio, billboards, and the products of the printing press have become the means of creating a large part of the demand that causes goods to depart from the factories to the ultimate consumer. It would be unjust to recognize a rule that would permit manufacturers of goods to create a demand for their products by representing that they possess qualities which they, in fact, do not possess; and then, because there is no privity of contract existing hetween the consumer and the manufacturer, deny the consumer the right to recover . . . Baxter v. Ford Motor Co., 168 WVash. 456, 462-63, 12 P.2d 409, 4 I2 (1932). 
Court treatment, goodwill development and protection is completely ignored. In one situation (end use interchangeability) advertising can generate "meaningful competition," 65 in a nother set of circumstances, "advertising advantages ... would dissuade new entrants and discourage active competition . . . ".166 A consistent point of reference is obviously lacking. Yet despite the clashes in ratiocination, one point is emerging. Mass-media-produced product differentiation is now one of the most forceful elements in antitrust prosecution. What was originally a concomitant to barriers to entry is gradually assuming the proportions and vitality of a distinct antitrust norm. lts sphere of influence is no longer conclusively tied to the barriers-to-entry concept. Whenever manifestations of product differentiation are clearly discernible, the possibility that the scales will tip in favor of the government is becoming greater.

\section{A. Product Differentiation and the Information-Persuasion Classification}

The best way to get a meaningful insight into mass-mediagenerated product differentiation as it impinges on trade regulation is to approach it in terms of the conventional informational and persuasive dichotomy. It must be emphasized that this classification has great appeal. For one thing, it is, at least ostensibly, a neat and orderly tangible-intangible juxtaposition. The boundaries of the informational message are thought to be easily ascertainable since its content is assumed to be verifiable by chemical analysis and performance tests. The overtones of objective product standardization and grading are readily apparent. ${ }^{167}$ Moreover, informational advertising has social utility: it serves to educate the public as to possible alternative product choices. As part of an educational scheme, the messages are designed to evoke rational responses, thus encouraging the consumer to make purchasing decisions on the basis of "facts." In short, informational advertising is universally viewed as being a valuable feature of the marketplace. ${ }^{168}$

Where commercial expressions of mass media are involved, information conveyance has become the borderline of

\footnotetext{
${ }^{165}$ United States v. Continental Can Co., 378 U.S. 441, 456 (1964).

${ }^{166}$ FTC v. Procter \& Gamble Co., 386 U.S. 568, 575 (1967).

${ }^{167}$ C. Wilcox, Public Policies Toward Business 609 (3d ed. 1966). For a contra view see

J. BACKMAN, AdVERTISING AND COMPETITION 32-33 (1967).

${ }^{168} 386$ U.S. at 603 (concurring opinion).
} 
acceptability-anything beyond this standard is automatically suspected as being injurious to the general public interest and particularly to free competitive movement in the marketplace. ${ }^{169} \mathrm{lt}$ is a standard that has been absorbed into the literature of the cases without serious challenge. This is unfortunate; an examination of the information-persuasion line of demarcation raises questions, the relevance of which is compounded by the fact that product differentiation is becoming more and more to be seen as a mere manifestation of persuasive mass media.

If the above views have validity it must be possible to draw a clear line between information and persuasion. This is an extremely difficult burden to meet. It has been correctly pointed out that "the line between information and influence in advertising is a thin one." 170 At what point on the scale of realistic decision making can it be said that the informational function crosses the line and becomes persuasive? Commentators, as mentioned previously, relate informational advertising to consumer education or, more specifically, to ensuring that the public is aware of the arrival of new products and is knowledgeable of possible alternative buys, and thus has the opportunity to make a free choice unencumbered by the "illusions" of persuasion. ${ }^{171}$ Presumably the educational process would be accomplished primarily through the circulation of research data, perhaps something similar to Consumer Reports. ${ }^{172}$ ldeally, product evaluation and selection would be conducted exclusively on the basis of brute and irreducible facts. Yet by definition all media forms involve some sort of fact utilization and by law all fact representation must be truthful. ${ }^{173}$ The issue, restated, is what causes informational facts to become persuasive utterances.

The advertising industry uses a two-stage method of analysis in

${ }^{169}$ See note 72 supra.

${ }^{170}$ W. MoORe, The Conduct of the CoRporation 275 (1962).

${ }^{171}$ Brown, Advertising and the Public Interest: Legal Protection of Trade Symbols, 57 YALE L.J. 1165, 1182-83 (1948).

${ }^{172}$ Turner contends that "the most promising approach is to introduce new sources of consumer information. It is the extent of uncertainty about the relative merits of competing products which contributes to the large effect of advertising, and this suggests that Government policies be directed toward neutral vehicles of information which tend to deal directly with the uncertainty." Turner, Advertising and Competition, 26 FED. B.J. 94,97 (1966).

${ }^{n 3}$ The question has been raised as to the possibility that persuasive advertising might, on closer analysis, be "false" under the statutory meaning of the term. "More complicated, from the Commission's standpoint, are the questions raised by the critics as to the false social values of advertising. The line between false value and actionable false promise may sometimes be hard 
making the distinction. First, a persuasive fact is extraneous to the primary purpose of the product; it is instead concerned with a side issue. Toothpaste does more than clean teeth, its basic objective; it also purifies your breath, which gets you a better job, a girl friend, etc. The second feature of the persuasive fact is that it is implanted by the use of redundant advertising tactics on a saturation level-perhaps more appropriately described as a deluge of trivia. ${ }^{174}$ The Supreme Court apparently has adopted an approach that is predicated on the existence of a rational consumer. If the consumer is aided in making a rational selection, he has been informed. When, however, the products are physically and chemically identical, an implicit presumption arises that any advertising activity is persuasive. What other explanation can there be for the fact that one brand will sell at a higher price than the competition's similar product? Fungible products such as sugar, ${ }^{175}$ tobacco,,${ }^{176}$ beer, ${ }^{177}$ gasoline, ${ }^{178}$ evaporated milk, ${ }^{179}$ and household bleach ${ }^{180}$ have each had their market success attributed to the differentiating capacities of persuasive mass media. Professor Bain, the leading exponent of product differentiation, defines persuasive mass media in rather vague terms. According to him, "generally phrased praises of the attributes of various outputs . . . or simply dinning into the potential buyer's mind an awareness of the product through endless repetition" 181 is persuading.

Regardless of the approach adopted, the division between informing and persuading is, at best, shadowy and blurred. What constitutes a side issue and at what point can it be said with assurance that a promotional saturation point has been reached? Moreover, the

to draw . . . . In short, advertising's new 'promise,' according to the social critic, is not directed to how the product will function but how it will satisfy our avarices or inadequacies." Millstein, The Federal Trade Commission and False Advertising, 64 Colum. L. Rev. 439, 447 (1964).

${ }^{174}$ Bursk, Advertising in Adversity, in J. Wright \& D. WARnER, SPEAKING OF ADVERTISING 169 (1963). Not all advertisers embrace the "hard sell" approach. See E. BrinK \& W. KELLEY, The Management of Promotion 145-46 (1963).

"13 Sugar Institute, Inc. v. United States, 297 U.S. 553 (1936).

${ }^{176}$ American Tobacco Co. v. United States, 328 U.S. 781 (1946).

${ }^{177}$ United States v. Pabst Brewing Co., 384 U.S. 546, 559 (1966) (Harlan, J., concurring); FTC v. Anheuser-Busch, 363 U.S. 536 (1960).

"FTC v. Sun Oil Co., 371 U.S. 505 (1963) (concerning price differential between "premium" and "regular" brands of gasoline).

${ }^{179}$ FTC v. Borden Co., 383 U.S. 637 (1966).

${ }^{180}$ FTC v. Procter \& Gamble Co., 386 U.S. 568 (1967).

"' J. Bain, Industrial Organization 227 (2d ed. 1968). Bain continues: "Thus an important category of product differentiation is built primarily on a nonrational or emotional basis, through the efforts of the 'ad-man.' "Id. 
classification is predicated on the shaky assumption that the public can be informed, and thereby educated, through what amounts to a type of classroom technique-i.e., the dissemination of factual data in understandable language. Such a view is, of course, totally unrealistic; the impersonal nature of the modcrn marketplace presents an insurmountable obstacle to clear communication. In today's "uninformed market, the buyer is ill-equipped to make a rational comparison among competing offers; as a result, he is usually unable even to demand the right kind of information."182 Even when the consumer's self interest is at stake, the specifics of factual information are not always absorbed. ${ }^{183}$ If the distinction is keyed to product similarity, a problem of definition arises. "What," Mr. Turner has querried, "are 'physically indistinguishable' products? Suppose a chlorine bleach producer puts a few drops of ammonia in his product, which is then called 'fortified' .... Is a package part of 'product?' "184

Perhaps a line could be drawn that would separate informational from persuasive advertising. The fact remains, however, that the gray questionable area on either side of this "line" would be too wide and too debilitating to, except in the obvious cases, furnish a basis of measurement sufficiently precise for meaningful analysis.

\section{B. Mass-Media Product Differentiation as Anticompetitive Conduct}

Defining product differentiation along the lines of "persuasion," and thereby invoking all of the unfavorable connotations associated with a form of activity that seemingly has little or no social value, is unquestionably one of the reasons that the concept is now a familiar ancillary target in antitrust prosecution. Building brand preferences predicated on the exploitation of subsidiary product qualities, which presumably result in a total waste of resources, presents an open invitation to attack, and the fact that this can ultimately result in the blocking out of potential competitors and in internal market disturbances, provides even more justification for the use of product differentiation as an aggressive trade regulation weapon.

\footnotetext{
${ }^{182} \mathrm{~T}$. Scitovsky, Welfare ANd Competrtion 426 (1951).

${ }^{183}$ The difficulties of consumer education, despite self interest, are reflected in Dehydrating Process Co. v. A.O. Smith Corp., 292 F.2d 653, 656 (1st Cir. 1961).

${ }^{184}$ Turner, Conglomerate Mergers and Section 7 of the Clayton Act, 78 HARv. L. Rev, 1313, 1337 (1965).
} 
Nevertheless, up to now, product differentiation has been utilized only as a tool or conduit through which a more dominant goal, the maintenance of desirable market structures, can be reached. If there were any doubts about product differentiation being an integral part of structural analytics, they were erased by Procter \& Gamble. Procter \& Gamble's advertising capacity and expertise could, so the Court reasoned, "substantially reduce the competitive structure of the industry by raising entry barriers and by dissuading the smaller firms from aggressively competing . . . ."185

But, as pointed out earlier, the Procter \& Gamble decision is more than an exercise in structural analytics. Advertising, which in 1946 had been characterized as "a powerful offensive and defensive weapon" in American Tobacco Co. v. United States, ${ }^{186}$ must now be considered to be fast approaching the status of "one of the congeries of anticompetitive practices at which the antitrust laws are aimed."187 The burden of establishing a nexus between product differentiation and adverse structural changes is clearly getting less onerous. There exists an undercurrent of feeling that mass-media activity in the marketplace deserves what amounts to per se prohibition. Bain says that " $[\mathrm{m}]$ easures to restrict advertising expenditures, either absolutely or by taxation, may be considered as potentially in the public interest." 188 Turner suggests "an absolute or percentage limitation on promotional expenditures by . . . firms that have obtained undue market power through violations of the Sherman Act."189 Professor Caves argues that "the effective amount of product differentiation might be pulled down" through taxation of advertising, "by requiring standardized labeling of some branded goods, and by attacking certain distribution practices . . . ."

Despite an expanding concern over the persuasive elements of product differentiation, as a practical matter great difficulty would be encountered in reaching the practice under the prevailing interpretation of trade regulation laws. Other than section 7 of the Clayton Act, which, of course, requires a merger as a prerequisite to prosecution, the only other statute that might lend itself to use is

\footnotetext{
${ }^{18 s}$ FTC v. Procter \& Gamble Co., 386 U.S. 568, 578 (1967).

${ }^{186} 328$ U.S. 781, 797 (1946).

${ }^{137}$ FTC v. Consolidated Foods Corp., 380 U.S. 592, 594 (1965).

188 J. Bain, Barriers to New Competition 217 (1965).

${ }^{189}$ Turner, supra note 172 , at 96.

${ }^{190}$ R. Caves, American Industry: Structure, Conduct, Performance 114 (2d ed. 1967).
} 
section 5 of the Federal Trade Commission Act. ${ }^{191}$ It has been suggested that the implementation of a strict and hard interpretation of section 5 would impose "an absolute standard of truth in advertising"192 and thereby eliminate mass-media comparisons of different branded but similar products. The emphasis on side issues and on "technical and half-truths"193 would presumably disappear. "[O]nly comparisons that referred to a significant difference as viewed by the buyer would be permitted." 194

The stresses of a "hard-line" application of section 5 would present the Federal Trade Commission with some imposing problems. The distinction between "absolute truths" and the condemned persuasions of puffing, "half-truths," and side issues would have to be made. The difficulties generated by such an endeavor have already been noted. ${ }^{195}$ In this case, however, there would be an added burden. The Commission would be confronted with an inquiry akin to the "like grade and quality" jurisdictional requirement under the Robinson-Patman Act. ${ }^{196}$ Products with different labels would first have to be classified as similar before the "absolute truth" standard would apply.

Another approach would be to hold that mass-media expenditures over a prescribed level would raise a rebuttable presumption of an unfair method of competition. This method of attack is clearly not. compatible with some of the institutional pressures of a mass-media culture that have been discussed in earlier portions of this article. Quantification in terms of budgetary expenditures is too illusory and too fragile a base upon which to rest antitrust prosecution. For one thing, the intangibles of consumer psychology, which Bain considers to be "the root of the trouble," 197 are ignored. Moreover, it is virtually impossible to isolate mass-media-inspired product differentiation expenditures from the broad sales expense category and, to compound the problem further, there are substantial difficulties in separating

\footnotetext{
${ }^{191}$ This Act makes unlawful "unfair methods of competition in commerce, and unfair or deceptive acts or practices in commerce." 15 U.S.C. $\S 45$ (a) (1958).

${ }^{192}$ Baum, Antitrust Functions of the Federal Trade Commission: Area Discrimination and Product Differentiation, 24 FED. B.J. 579, 603 (1964).

${ }^{193}$ Id.

ist Id.

${ }^{105}$ See notes 174-84 supra and accompanying text.

${ }^{196}$ See notes 84-96 supra and accompanying text.

${ }^{197} \mathrm{~J}$. BAIN, supra note 188, at 216 . "For all of these reasons, it is difficult to attaek this sort of barrier to entry under laws in the anti-monopoly or anti-collusion tradition, or to legislate it away." Id.
} 
sales expenditures from production costs. ${ }^{198}$ For example, can valid and meaningful product improvements always be distinguished from changes in style? ${ }^{199}$ Pricing, which normally might be assumed to be a component of product policy, can in reality constitute a form of product differentiation in that high price is, in the consumer's mind, equated with status and prestige. The Cadillac automobile is an example. Another problem would be successfully relating the informational-persuasive distinction to the concrete expenditure figures of the balance sheet. Presumably, information expenditures would be permissible, i.e., immune to attack. Yet, it is doubtful if an accounting methodology could be implemented that could make valid budgetary allocations on the basis of a division so nebulous as information-persuasion. ${ }^{200}$

Even if informational advertising could be identified and its expenditures segregated, it might, because of "spectrum scarcity,"201 be a meaningless accomplishment. There are only so many communication outlets in a given region. Those companies able to draw upon substantial financial resources could buy large chunks of time or space and saturate the public with informational messages. Smaller competitors would thus be blocked out from access to the public. ${ }^{202}$ The results would be not unlike those attained by "persuasive" tactics.

198 See E. Chamberlin, The Theory of Monopolistic Competition 123-24 (8th ed. 1962).

199 W. Carter \& W. SNavely, INTERMediate Economic ANalysis 208 (1961).

${ }^{20}$ In discussing efficiency and advertising within the context of the Procter \& Gamble case, Bork says: "It is very doubtful, to say the least, that the informative and market-entrenching aspects of advertising can be separated according to dollar amounts spent. In fact, it seems doubtful that they can be separated at all. Absent the advertising of Clorox, the company Procter \& Gamblc acquired, there would certainly not have been as many people aware and regularly reminded of the existence and uses of liquid bleach. The output of the entire liquid bleach industry would undoubtedly be far lower if advertising were seriously inhibited. But if Clorox performs this informational service, it must pay for it. The only means it has of recovering the costs and making a return on the activity is through the sale of its product, and in this case it charged a somewhat higher price. This illustrates that where advertising is involved the informational function and the market-entrenching function are necessary to each other and cannot exist separately." Bork, Contrasts in Antitrust Theory: I, 65 Colum. L. Rev. 401, 411 n.11 (1965) (emphasis added).

201 "Spectrum scarcity" is a term that describes the rationale for governmental regulation of broadcasting. See generally Robinson, The FCC and the First Amendment: Observations on 40 Years of Radio and Television Regulation, 52 MINN. L. REv. 67 (1967).

${ }^{202}$ Professor Moore notes that "since the attention of potential customers have finite limits and since the number of channels for gaining attention havc even narrower limits, saturation of information channels may suggest itself as a way of shutting out competing messages." W. MOORE, supra note 170, at 259. 
Above and beyond the objections to absolute product differentiation prohibition already discussed, ${ }^{203}$ there exists a possible constitutional obstacle. Does commercial persuasion so adversely affect society as to justify dropping first amendment safeguards? The answer is probably no. The great distance between false and misleading advertising, which does not receive nor deserve constitutional protection, ${ }^{204}$ and the saturation puffing about incidental product qualities, should serve to preclude sanctions against the usual run of marketplace promotion activity. ${ }^{205}$ Although this point is as yet in some doubt, ${ }^{206} \mathrm{Mr}$. Justice Douglas' remark that "those who make their living through exercise of First Amendment rights are no less entitled to its protection than those whose advocacy or promotion is not hitched to a profit motive, ${ }^{207}$ certainly reflects a commitment to the constitutional protection of commercially oriented mass-media efforts. ${ }^{208}$

\section{The Solution: A Change of Perspective}

The 'Differentiation of the Product' is by all odds the most difficult subject of all, and the reason is not hard to see. It contains, not a technique, but a way of looking at the economic system; and changing one's economic Weltanschauung is something very different from looking into the economics of the individual firm or adding new tools to one's kit. ${ }^{209}$

Product differentiation, the only concept in economics and trade regulation which is specifically committed to ascertaining the effects of mass-media impulses, has not received treatment that is in focus

${ }^{203}$ Discussion of industry self-regulation has been omitted on the basis that these plans are, in broad scope and impact, ineffeetive. See generally Baum, Self Regulation and Antirust: Suppression of Deceptive Advertising by the Publishing Media, 12 SYRacuSE L. REV. 289 (1961).

${ }^{204}$ Donaldson v. Read Magazine, Inc., 333 U.S. 178, 189-90 (1948).

${ }^{205}$ Of course, it could be argued that any advertising that is not strictly informational is "false." See note 173 supra. However, the problems of separating informational mass media from other forms raises insurmountable obstacles to this approach.

${ }^{206}$ For an excellent discussion of the constitutional issues see Developments in the Law-Deceptive Advertising, 80 HARv. L. REv. 1005, 1027 (1967).

${ }^{207}$ Cammarano v. United States, 358 U.S. 498, 514 (1959) (concurring opinion). See generally Note, Freedom of Expression in a Commercial Context, 78 HARv. L. REv. 1191 (1965).

${ }^{208}$ To further cloud and complicate the problem of whether prohibition of advertising per se is constitutional is the emerging recognition of the TV commereial as an art form. Tyrmand, $A$ Reporter at Large: American Diary, THE NEw YoRker, Nov. 11, 1967, at 67, 106-08. See also Gould, Commercials Can be Artistic-And Awful, N.Y. Times, Nov. 26, 1967, § D at 19.

${ }^{209}$ E. Chamberlin, supra note 198, at 204-05. 
with the contemporary environment. Likewise, in those antitrust cases in which mass media has been a peripheral factor, analysis has been uneven.

The dominant problem is the lack of reliable data. If answers are to be extracted from existing information, the conflicts over mass media as a waste of resources, as added "value," or as a mandatory component of the age of consumption, will never be satisfactorily resolved. Compared to gauging the effects of mass media, structural changes, forms of conduct, and performance patterns are relatively easy to observe and measure. The only difficulty is the amount of weight to be assigned the results of the examination - at what point on the measuring scale is relief justified? On the other hand, mass media defies this type of analysis. It is a force too expansive to be fragmatized. The fact that its main thrust is cerebral makes reification into balance sheet figures extremely difficult and often meaningless. Moreover, the social ramifications of media techniques operating on the populus have thus far precluded dispassionate inquiry.

Since mass media does exude substantial influences of present effect on society and the economy, it is mandatory that a frame of reference, constructed around broad guidelines of analysis, be created for immediate use. The basic objective of this "new perspective" is to develop a common thread of inquiry for application to the diverse mass-media problems. The basic sense of direction for the new perspective would spring from an acknowledgement of the credence of five propositions:

1. A consciousness of the dearth of worthwhile data on the problem must be developed. This implies the collection of information, devising methods of measurement, and the calabration of findings with the institutional features of mass media. This is obviously a long range commitment; nevertheless, an awareness of the necessity of its accomplishment furnishes an important background for the implementation of the new perspective.

2. A realization of the totality of mass media's institutional impact on the economic processes is fundamental. Little elaboration on the validity of this point is necessary-much of this article has focused on this conclusion.

3. Mechanical and conclusive assumptions as to the anticompetitive effects of "persuasive" mass media must be avoided. Available information simply does not support such an assumption. Courts should be prepared to balance the known consequences of 
advertising, promotion, etc., against other interests. In other words, the validity of mass media as a competing interest should be recognized.

4. Proscription of mass media, under the guise of product differentiation, "persuasive" promotion, or any other characterization is untenable.

5. The final element to be acknowledged is the lack of evidence for the view that advertising, promotion, and other mass-media efforts are incompatible with antitrust objectives. While a factor of immense vigor, there is no empirical evidence leading to the inevitable conclusion that mass media interferes with the Turner description of antitrust policy..$^{210}$

The abstractionism of the "new perspective" is obvious. It is, at best, a tentative step. Nevertheless, its immediate impact on the problem areas discussed in this article cannot be discounted. Where, for example, the Robinson-Patman jurisdictional obstacle of "like grade and quality" is at issue, the Court would give judicial recognition to discernible manifestations of persuasive mass media. As a start, the same standards presently used to ascertain the existence of "premium" and "regular" products under section 2(b) could be invoked. More sophisticated analysis might follow.

Where new media technologies impinge on antitrust, the new perspective suggests that they be analyzed with full cognizance of the existence of unique and subtle problem areas. Specifically a new stare decisis should be developed for television. As a beginning point, strict consistency of transmission should not be required. Emphasis should be on what the viewer apprehends from his TV screen. With the collection of additional data, perhaps the third transmissional stage-the impact on the viewer's psyche-will become relevant, or maybe even crucial.

A balancing-of-interest methodology is indicated in the tying arrangement, goodwill and franchise areas. Recognition should be given the possibility that mass-media inspired goodwill influences outweigh adverse competitive effects in these two situations. Where goodwill is crucial in the improvement of market structures, in breaking into markets, or fending off large rivals, it should be taken into consideration. The same balancing-of-interests philosophy could

${ }^{210}$ Turner, The American Antitrust Laws, 18 MODERN L. Rev. 244 (1955). 
be relevant in cases involving economies of advertising and promotion.

The Continental Can decision's channeling of mass media into a cross-elasticity-of-demand treatment of the relevant product market is compatible with the new perspective. In that instance there was a full recognition given to the thrust of persuasive promotional techniques on the consumer.

Analysis of mass media as a factor in the erection of market barriers poses a taxing problem to the new perspective. Nevertheless, one point is clear: product differentiation should not be thrown into the harmful-conduct classification. For the reasons developed in this article, it would be advisable to attach subsidiary importance to product differentiation. Even using this concept as an ancillary weapon, courts should move with caution. Quantification of the advertising budget should not, as it did in Procter \& Gamble, constitute the sole criterion by which to ascertain and measure product differentiation. 
